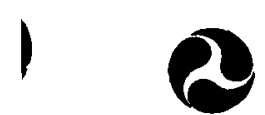

U.S. Department

of Transportation

Mationel tighway

Traific Seriey

Administration

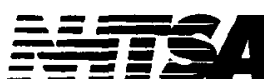

People 8aving Peoplo

innuhtaradoter

DOT HS 860322

August 2001

\title{
Older Road User Research Plan
}


This publication is distributed by the U.S. Department of Transportation, National Highway Traffic Safety Administration, in the interest of information exchange. The opinions, findings and conclusions expressed in this publication are those of the author(s) and not necessarily those of the Department of Transportation or the National Highway Traffic Safety Administration. The United States Government assumes no liability for its content or use thereof. If trade or manufacturer's names or products are mentioned, it is because they are considered essential to the object of the publication and should not be construed as an endorsement. The United States Government does not endorse products or manufacturers. 
Technical Report Documentation Page

\begin{tabular}{|c|c|}
\hline \begin{tabular}{ll|l} 
1. Report No. & 2. Government Accession No. \\
& DOT HS 809322 &
\end{tabular} & 3. Recipient's Catalog No. \\
\hline \multirow[t]{2}{*}{$\begin{array}{l}\text { 4. Title and Subtitle } \\
\text { Older Road User Research Plan }\end{array}$} & $\begin{array}{l}\text { 5. Report Date } \\
\text { August, } 2001 \\
6 \text { Performina Oraanization Code } \\
\end{array}$ \\
\hline & 8. Performing Organization Report No. \\
\hline \multicolumn{2}{|l|}{$\begin{array}{l}\text { 7. Author(s) } \\
\text { P. Raymond, R. Knoblauch, M. Nitzburg }\end{array}$} \\
\hline \multirow{3}{*}{$\begin{array}{l}\text { 9. Performing Agency Name and Address } \\
\text { Center for Applied Research } \\
9661 \text { Fringe Tree Road } \\
\text { Great Falls, VA 22066-1901 }\end{array}$} & 10. Work Unit No. (TRAIS) \\
\hline & $\begin{array}{l}\text { 11. Contract or Grant No. } \\
\text { DTNH } 22-99-D-15099\end{array}$ \\
\hline & 13. Type of Report and Period Covered \\
\hline \multirow{2}{*}{$\begin{array}{l}\text { 12. Sponsoring Agency Name and Address } \\
\text { Office of Research and Traffic Records } \\
\text { National Highway Traffic Safety Administration } \\
400 \text { Seventh Street, SW } \\
\text { Washington DC } 20590\end{array}$} & research report \\
\hline & 14. Sponsoring Agency Code \\
\hline
\end{tabular}

\section{Supplementary Notes}

\section{Abstract}

In 1999, the Transportation Research Board convened a meeting to discuss older road user issues. Many research and implementation ideas were generated at that conference, though not all of them fell within NHTSA's mission. In order to identify which research investigations NHTSA should pursue in the coming years, a contract was let to the Center for Applied Research. Under this contract, they conducted a literature review and convened an expert panel meeting to identify which of the research and implementation ideas could be pursued by NHTSA, and how much each investigation would cost. Research problem statements were generated for each topic that was identified as a priority. This report contains a summary of the activities conducted under this contract, as well as the research problem statements. It also contains three potential schemes for conducting the potential research over seven years.

\section{Key Words}

older driver, research programs, pedestrian, highway safety
18. Distribution Statement

No restrictions.

\begin{tabular}{|l|l|l|l|}
\hline $\begin{array}{l}\text { 19. Security Classif. (of this report) } \\
\text { Unclassified }\end{array}$ & 20. SECURITY CLASSIF. (of this page) & 21. No. of Pages & 22. Price \\
\hline
\end{tabular}

Form DOT F 1700.7 (8/72) Reproduction of form and completed page is authorized. 


\section{TABLE OF CONTENTS}

EXECUTIVE SUMMARY

$\begin{array}{lc}\text { BACKGROUND } & 4\end{array}$

$\begin{array}{ll}\text { EXPERT PANEL } & 7\end{array}$

Table 1 High-priority Research and Implementation Projects 10

Table 2 Medium-priority Research and Implementation Projects

PROBLEM STATEMENTS

Maryland Model Follow-up $\quad 17$

Law Enforcement Program: Detecting Impaired Drivers 18

Driver Retraining Evaluation $\quad 19$

Driver Retraining Standards: Standardization of Training and Standards of Driver

Rehabilitation/Assessment Professionals $\quad 20$

Screening and Assessment: Development, Evaluation and Validation of Tools 21

Screening and Assessment: Types/Tiers of Assessments 22

Screening and Assessment: Screening - Routine or Focused?

Screening and Assessment: Referral Programs $\quad 24$

PI\&E: Overall Awareness Level $\quad 25$

PI\&E: Evaluate PI\&E Efforts - new and old 26

Evaluate Mobility Alternatives $\quad 27$

Mobility Alternatives PI\&E $\quad 28$

Alternative Transportation Users: Needs And Capabilities 29

Rate of Impaired Status $\quad 30$

Assessment of Medication Effects on Driving 31

ITS and Implications for At-Risk Drivers

Media Portrayal of Older Drivers

National Personal Transportation Survey (NPTS) - Analysis

Overcoming Barriers to Driver Assessment

Early-Stage Dementia Driving Behavior Research 36

Indiana Tri-Level, Update $\quad 37$

Medical Conditions: Do They Impede Insight for Self-Regulation?

Rural Older Drivers, Crashes, and Exposure

Crashes Involving Older Pedestrians $\quad 40$

Crash Rates of Older Females: Cohort Effect?

$\begin{array}{ll}\text { PRIORITIZATION } & 42\end{array}$

STRICT VOTE-BASED PRIORITIZATION

Table 3 Timeline for Strict Vote-Based Prioritization 44

DIVERSIFICATION STRATEGY

Table 4 Timeline for Diversification Strategy Prioritization 46

TOPIC C.OVERAGE PRIORITIZATION

Table 5 Timeline for Topic Coverage Prioritization 48

$\begin{array}{ll}\text { REFERENCES } & 49\end{array}$ 


\section{APPENDICES}

Appendix 1 - Literature Review

Appendix 2 - Research Projects Suggested and Prioritized at the November, 1999 Meeting Included in Literature Review of Current Project

Appendix 3 - Implementation Projects Suggested and Prioritized at the November, 1999 Meeting Included in Literature Review of Current Project

Appendix 4 - Unprioritized General Research Concepts Suggested at the November, 1999 Meeting Included in Literature Review of Current Project

Appendix 5 - Unprioritized General Implementation Concepts Suggested at the November, 1999 Meeting Included in Literature Review of Current Project

Appendix 6 - Additional Research and Implementation Projects Identified During the Review of Research and Materials

Appendix 7 - Additional Research Projects Proposed by Expert Panel Members 


\section{EXECUTIVE SUMMARY}

NHTSA has long been involved in research efforts regarding older drivers. Over the last several years, NHTSA's focus has shifted from all older drivers to attempts to identify those older drivers and pedestrians who have problems. Safety is the first priority, with mobility a strong second.

In November of 1999, the Transportation Research Board held a conference (Transportation in an Aging Society: A Decade of Experience) to establish the state of knowledge concerning the transportation issues of older people and to explore how that knowledge has changed over the last decade.

Participants at that conference generated a prioritized, unfiltered list of research and implementation ideas. This list included over 50 possible research topics. Many fell within the NHTSA mission, but some clearly did not, and many required a scope of effort that would be beyond the budget available for this line of research.

The Center for Applied Research was asked to use the November 1999 conference list as a starting point to generate a list of research projects that fall within NHTSA's mission and have the greatest potential impact on safety. The ultimate goal was to formulate a strategic research plan for NHTSA's Office of Research and Traffic Records. For planning purposes, an annual budget of about $\$ 500,000$ was assumed for a seven-year time frame ( $\$ 3.5 \mathrm{M}$ total).

The strategic research plan was to be developed through the preparation of a Literature Review, the meeting of an Expert Panel, the development of Problem Statements, and the creation of Prioritization Schemes.

A Literature Review was prepared and is included as an appendix to this report. It concentrated on advances in the last 10 years, and aimed for breadth rather than depth of coverage. The review provided a brief, readable summary of research efforts aimed at the at-risk population. The audience was the panel of experts to be convened in November, 2000. The review was intended to give these panelists a common frame of reference when discussing projects, and was not intended to be an exhaustive review for the general population.

The Literature Review was also used to identify additional research and implementation projects. These potential projects included efforts in previously examined areas and new research/implementation topics. These, as well as the previously-generated potential research and implementation projects, are presented in tabular form.

An Expert Panel was convened to discuss and evaluate potential projects. The meeting was designed to elicit raw information which would later be used to develop prioritization schemes. for research planning. The members of the Panel included top representatives from the fields of traffic engineering, human factors, traffic safety, aging, geriatrics, law enforcement, the American Association of Motor Vehicle Administrators (AAMVA), and AARP.

The Expert Panel reviewed the previously-generated list of potential projects, generated additional potential projects, and prioritized the projects (High, Medium, and Low Priority) according to the importance of safety urgency, practicality and feasibility. 19 projects received a High Priority rating from the Expert Panel members. Panel members voted on these High Priority projects to establish a rough relative priority.

When multiple studies addressed a common topic or issue, the Expert Panel members often decided to "fold them together" as packages. A project package (with multiple studies) was then treated as a unit. Panelists suggested that these projects might be later "folded out" again, either individually or in subpackages, for prioritization.

The Expert Panel recommended a variety of research efforts to enhance safety. In general, the Expert Panel recommended continued investigation of screening and assessment issues, development of training for law enforcement, evaluation of driver retraining programs, and development of public information and education efforts. Among others, efforts were recommended to examine effects on 
safety caused by such diverse issues as medication use, medical conditions including early-stage dementia, and ITS technology use. Panelists also recommended examinations of mobility alternatives, and a general information-gathering effort through the National Personal Transportation Survey.

As recommended by the Expert Panel, large multi-study packages were redivided into subpackages. A subpackage could be a single study, but more commonly was formed by a small number of individual studies which shared a common issue or method. These subpackages formed smaller packages than the large packages folded together by the Expert Panel.

Using information gathered from the potential project descriptions, the Literature Review, and the Expert Panel, problem statements were generated for each High Priority project. Problem statements list a Title, Problem, Objective/s, Related Work, and Cost for each project.

Using the information and recommendations given by the Expert Panel, as well as information from the Literature Review, three Prioritization Schemes were developed. Each prioritization is described briefly and is illustrated by a Gantt chart, which presents a timeline and funding levels for the projects over a 7 year span.

The Strict Vote-Based Prioritization strictly followed the votes given by the Expert Panel (votes were cast on the basis of safety urgency, practicality and feasibility). The top-voted projects were assigned highest priority. The projects were spaced out through the 7-year time frame.

The Diversification Strategy gave greater emphasis to the cost of individual projects. If top prioritization were assigned to a few very large projects, given budget limitations, a single expensive project could tie up all available resources in a given calendar year. This would limit the type of outcomes that could be produced. In order to diversify the investment in different research areas, lower-cost projects, from a wider range of topic areas, were assigned a higher priority. In order to spread out the investment, overlapping topic areas were limited. If two projects covered the same topic area, the less-expensive project was recommended. It is clear that a greater number of projects is funded in this approach: giving up a large project enables the funding of several smaller investigations.

The Topic Coverage Prioritization examined high-priority projects in terms of topic coverage. This scheme maximizes coverage of high-priority topic areas, with a special emphasis on feasibility. Overlap of topics was minimized, with attention paid to topic coverage rather than cost. In general, less emphasis was placed on retaining multi-study packages in their entirety. When subpackages or individual studies assisted in topic coverage, they were "folded back out" and assigned to the timeline. 


\section{BACKGROUND}

The National Highway Traffic Safety Administration's (NHTSA's) mission is to save lives, prevent injuries, and reduce traffic-related health care and other economic costs. The agency develops, promotes, and implements effective educational, engineering, and enforcement programs directed toward ending preventable tragedies and reducing safety-related economic costs associated with vehicle use and highway travel (Statement of Work, DTNH22-99-D-15099).

NHTSA has long been involved in research efforts regarding older drivers. Over the last several years, NHTSA's focus has shifted from all older drivers to attempts to identify those older drivers and pedestrians who are at risk. Safety is the first priority, with mobility a strong second.

In November of 1999, the Transportation Research Board held a conference (Transportation in an Aging Society: A Decade of Experience) to establish the state of knowledge concerning the transportation issues of older people and to explore how that knowledge has changed over the last decade. Participants at that conference generated a prioritized, unfiltered list of research and implementation ideas. This list included over 50 possible research topics. Many fell within the NHTSA mission, but some clearly did not, and many required a scope of effort that would be beyond the budget available for this line of research.

The Center for Applied Research was asked to use the November 1999 conference list as a starting point to generate a list of research projects that fall within NHTSA's mission and have the greatest potential impact on safety. The ultimate goal was to formulate a strategic research plan for NHTSA's Office of Research and Traffic Records. For planning purposes, an annual budget of about $\$ 500,000$ was assumed for a seven-year time frame $(\$ 3.5 \mathrm{M}$ total).

The strategic research plan was to be developed through the preparation of a Literature Review, the meeting of an Expert Panel, the development of Problem Statements, and the creation of Prioritization Schemes.

The Center for Applied Research was asked to conduct the activities necessary to define and prioritize NHTSA's future studies in this area. Toward this end, a literature review was conducted on the last 10 years' findings. This brief overview was provided to a panel of the top experts in the field. At a meeting on November 2, 2000, the Expert Panel reviewed and evaluated potential research projects. The results of the Expert Panel were compiled, and three prioritization schemes were developed to assist NHTSA in covering the most urgent, practical and feasible projects. These activities are described in this report. 


\section{LITERATURE REVIEW}

The purpose of the literature review was to provide a brief overview of some of the relevant literature that has been useful in identifying possible research and implementation problem statements. The body of the review is included as Appendix 1 . A full, comprehensive review of all of the relevant topic areas was not attempted. Those who wish a more detailed review are directed to the proceedings of the November 1999 meeting, when they become available.

The literature review concentrated on advances in the past 10 years, and aimed for breadth rather than depth of coverage. The review provided a brief, readable summary of research efforts aimed at the atrisk population.

The literature review's audience was the panel of experts to be convened in November, 2000. The panelists represented the top experts in a wide-ranging list of specialized topics. The review was intended to give these panelists a common frame of reference when discussing projects, and was not intended to be an exhaustive review for the general population.

In the body of the literature review (see Appendix 1), the following general topic areas were briefly addressed:

$\begin{array}{ll}\text { - } & \text { The At-Risk Population } \\ \text { - } & \text { At-Risk Drivers and Crashes } \\ \text { - } & \text { Censory/Perceptual Problems } \\ \text { - } & \text { Physical and Psychomotor Abilities } \\ \text { - } & \text { Errors Committed by Older Drivers } \\ \text { - } & \text { Older Pedestrians } \\ \text { - } & \text { Pdaptive Strategies } \\ \text { - } & \text { Design Countermeasures } \\ \text { - } & \text { Driving Cessation } \\ \text { - } & \text { Screening Instruments } \\ \text { Mobility Alternatives }\end{array}$

One of the major goals in conducting the review was to examine the existing state-of-the-practice so that additional potential research and implementation projects could be identified. These ideas could include additional efforts in previously examined areas as well as new research/implementation topics.

Potential research and implementation projects were listed in five separate tables that were provided to the Expert Panel members. These five tables are included as appendices. They include:

- $\quad$ Appendix 2: Research Projects suggested and prioritized at the November, 1999 TRB Conference. The research projects contained in this table are based on concepts developed and prioritized at the TRB meeting.

The table is organized into three columns. The first column describes a tentative title for the project while the second column indicates the general approach or type of study that could be used. The third, and perhaps most important, column describes the desired outcomes or basic research question to be answered. This listing and prioritization of potential projects were suggested at the November 1999 TRB Conference. However, the title and the general approach were developed by the authors of this report.

- $\quad$ Appendix 3: Implementation Projects suggested and prioritized at the November, 1999 TRB Conference. This table is organized the same as Appendix 1, except that the concepts involve implementation rather than research. A close examination of this table will reveal that the distinction between research and implementation is often a blurry one. The various concepts were classified (i.e., as "research" or "implementation") by the November 1999 TRB Conference. 
Many of the concepts suggested at the November 1999 TRB Conference consisted of relatively general issues that were not specific enough to allow either a title or research approach to be developed. Rather than discard these potentially useful concepts, they are presented in Appendices 4 and 5.

- $\quad$ Appendix 4: Unprioritized Research Concepts suggested at the November 1999 TRB Conference.

- $\quad$ Appendix 5: Unprioritized Implementation Concepts suggested at the November 1999 TRB Conference.

- $\quad$ Appendix 6: Additional Research and Implementation Projects identified during the Review of Research and Materials. This listing of potential projects consists of concepts that were identified during our review of the literature and relevant project materials.

It is important to emphasize that there was absolutely no effort to be critical of the concepts that were either suggested at the TRB conference or generated by the authors of this report. The goal was to gather an uncensored list of potential projects that were to be criticaliy evaluated at a later phase in the project. 


\section{EXPERT PANEL}

An Expert Panel Meeting was held on November 2, 2000 at the National Highway Institute in Arlington, Virginia. Ten top experts in the field of at-risk driver and pedestrian research participated in the discussion:

- Prof. Martin A. Pietrucha, Moderator, Pennsylvania Transit Institute, Pennsylvania State
University
Dr. Helen Kerschner, Beverly Foundation
- Jason King, American Association of Motor Vehicle Administrators
Dr. Rich Marottoli, Yale University
- Tina Abbate Marzolf, Area Agency on Aging 1-B, Michigan
- Kent R. Milton, AAMVA Consultant
- Dr. Richard Pain, TRB/NAS
Dr. Alison M. Smiley, Human Factors North
- Dr. Loren Staplin, Scientex Corporation
- Audrey Straight, AARP
Sgt. Tom Woodward, Maryland State Police

The purpose of the panel was to discuss potential research projects, add projects if necessary, determine feasibility and practicality, and discuss importance. The ultimate goal was for the panelists to provide the input which would be used to prioritize the most important projects for NHTSA to fund.

Prior to the meeting the panelists were given the Literature Review and Potential Projects (see Appendices 2-6). Panel members discussed the list of potential projects and were asked to add ideas that were not in the list (see Appendix 7 for list of panelist additions).

Panelists were asked to consider the potential projects and, as a group, assign to each project a High, Medium, or Low Priority rating. The panelists discussed each potential research project in detail in order to determine priority levels. Panelists considered the history of each topic, including past research efforts' results and implementation. Current related research was discussed, particularly with regard to overlap with the topic of interest. If a topic was at least partially covered by current or past work, the issue generally received a lower priority rating.

The discussion continued until the panelists reached a consensus regarding priority (driven by safety urgency, practicality and feasibility). Projects were assigned "High", "Medium" or "Low" priority. When multiple studies addressed a common topic or issue, the panel often decided to "fold them together" as packages. A project package (with multiple studies) was then treated as a unit. Panelists suggested that these projects might be later "folded out" again.

After all potential projects were assigned "High, Medium" or "Low" priorities, panelists examined the nineteen "High" NHTSA priority projects. Panelists were asked to vote for the projects they felt should be given the highest priority, given the importance of safety urgency, practicality and feasibility. Each panel member could vote for as many as nine projects. The resulting vote totals are shown in Column 1 of Table 1, High-priority Research And Implementation Projects.

A few of the multi-study packages are very large and include many studies. These have been broken down into subpackages. Subpackages are typically groups of 2-4 studies which logically might be performed together. With this approach, the sometimes unwieldy multi-study packages can have smaller units "folded out" without breaking down into single studies.

In Table 1, multi-study packages are ordered by descending numbers of votes, as shown in Column 1. That is, the packages receiving the greatest numbers of votes appear first, and those receiving the fewest appear later. No package received zero votes.

One caveat should be made regarding the votes given to each package. On average, the largest packages (usually those including several studies) tended to receive the most votes for priority. This is 
perfectly logical, as larger packages will generate more information. However, it means that the votes may have become skewed toward the larger packages.

In Table 1, "High-priority Research and Implementation Projects", "Votes" (Column 1) shows the number of priority votes a package received from the Expert Panel. "Level of Effort" (Column 2) shows the funding recommended by the Expert Panel for the package. "Package" (Column 3 ) shows the overall topic or title of a multi-study package. "Subpackage" (Column 4) shows the topic or title of the folded-out subpackage and the level of funding recommended for the subpackage if done independently from the rest of the multi-study package.

"Project Title"(Column 5) refers to the title of the potential project or concept from the Literature Review (or Expert Panel). The Expert Panel occasionally changed titles, but these are usually the same as those presented in the Literature Review. Although it is tempting to think of these as individual studies, many of the line items at this level would require multiple studies to fulfill the goals (for example, a project that calls for both the development and the validation of a screening instrument.)

"General Approach/Type of Study" (Column 6) shows the method recommended for the work. "Desired Outcomes" (Column 7) gives the goal, the question to be answered, or the desired product from the work.

In Table 2, the few Medium-priority Research and Implementation Projects are shown. Because the Medium-priority projects were not included in the vote and did not have a level of effort recommended by the Expert Panel, no votes or funding levels are shown. The Medium-priority projects were small efforts, so no multi-study titles or subpackages appear. Table 2 simply shows the Project Title, General Approach/Type of Study, and Desired Outcomes.

For both Tables 1 and 2, it is important to note that the descriptions are intended to serve only as summaries. Detailed Problem Statements follow and give a more complete description of each item. 


\begin{tabular}{|c|c|c|c|c|c|c|}
\hline \multicolumn{7}{|c|}{$\begin{array}{c}\text { Table 1 } \\
\text { High-priority Research and Implementation Projects }\end{array}$} \\
\hline Votes & $\begin{array}{l}\text { Level of } \\
\text { Effort }\end{array}$ & Package & $\begin{array}{c}\begin{array}{c}\text { Sub-package, } \\
\text { where } \\
\text { applicable }\end{array} \\
\end{array}$ & Project Title & $\begin{array}{c}\text { General } \\
\text { Approach/ } \\
\text { Type of Study }\end{array}$ & $\begin{array}{c}\text { Desired Outcomes } \\
\text { (Question to be Answered) }\end{array}$ \\
\hline 8 & $\begin{array}{l}\$ 500 \mathrm{~K} \\
\text { (without } \\
\text { in-kind) }\end{array}$ & $\begin{array}{l}\text { Maryland. } \\
\text { Model Follow- } \\
\text { Up }\end{array}$ & N/A & $\begin{array}{l}\text { The Maryland Model: } \\
\text { Further Testing }\end{array}$ & Pilot Test & $\begin{array}{l}\text { Further pilot test MD at-risk program } \\
\text { (test exportability) }\end{array}$ \\
\hline 7 & $\$ 300 \mathrm{~K}$ & $\begin{array}{l}\text { Law } \\
\text { Enforcement } \\
\text { Training }\end{array}$ & N/A & $\begin{array}{l}\text { Law Enforcement } \\
\text { Program: Detecting } \\
\text { Impaired Drivers }\end{array}$ & $\begin{array}{l}\text { Curriculum } \\
\text { Development }\end{array}$ & $\begin{array}{l}\text { Develop and validate training } \\
\text { programs for law enforcement to } \\
\text { spot problem drivers - provide } \\
\text { referral avenue (perhaps simplify } \\
\text { procedural referral). Avoid age } \\
\text { discrimination. }\end{array}$ \\
\hline \multirow[t]{3}{*}{7} & \multirow[t]{3}{*}{$\$ 4-500 \mathrm{~K}$} & \multirow[t]{3}{*}{$\begin{array}{l}\text { Driver } \\
\text { Retraining }\end{array}$} & \multirow[t]{2}{*}{$\begin{array}{l}\text { Retraining } \\
\text { Evaluation } \\
\$ 400 \mathrm{~K}\end{array}$} & $\begin{array}{l}\text { Do Assessment-and- } \\
\text { Retraining Programs } \\
\text { Improve Driving? }\end{array}$ & Evaluation & $\begin{array}{l}\text { Conduct follow-up of studies of } \\
\text { outcomes of assessment and } \\
\text { retraining programs, including } \\
\text { investigation of remediation } \\
\text { effectiveness }\end{array}$ \\
\hline & & & & $\begin{array}{l}\text { Evaluation of Older } \\
\text { Driver Training } \\
\text { Programs }\end{array}$ & Evaluation & Older driver training effectiveness \\
\hline & & & $\begin{array}{l}\text { Retraining } \\
\text { Standards } \\
\$ 100 \mathrm{~K}\end{array}$ & $\begin{array}{l}\text { Standardization of } \\
\text { Training and } \\
\text { Standards of Driver } \\
\text { Rehab/Assessment } \\
\text { Professionals }\end{array}$ & Expert Panel & $\begin{array}{l}\text { Identify research issues involved in } \\
\text { potential standardization of training } \\
\text { and standards of driver } \\
\text { rehab/assessment professionals }\end{array}$ \\
\hline 7 & $\$ 800 \mathrm{~K}$ & $\begin{array}{l}\text { Screening and } \\
\text { Assessment }\end{array}$ & $\begin{array}{l}\text { Development, } \\
\text { Eval and } \\
\text { Validation of } \\
\text { Tools } \\
\$ 300 \mathrm{~K}\end{array}$ & $\begin{array}{l}\text { Screening Battery } \\
\text { Development }\end{array}$ & $\begin{array}{l}\text { Development, } \\
\text { Evaluation, } \\
\text { Implementation }\end{array}$ & $\begin{array}{l}\text { Develop and evaluate, then } \\
\text { implement, screening tests for } \\
\text { visual, cognitive and/or physical } \\
\text { problems related to crashes (and } \\
\text { test training materials for } \\
\text { administrators) }\end{array}$ \\
\hline
\end{tabular}




\begin{tabular}{|c|c|c|c|c|c|c|}
\hline Votes & $\begin{array}{l}\text { Level of } \\
\text { Effort }\end{array}$ & Package & $\begin{array}{c}\text { Sub-package, } \\
\text { where } \\
\text { applicable }\end{array}$ & Project Title & $\begin{array}{c}\text { General } \\
\text { Approachl } \\
\text { Type of Study } \\
\end{array}$ & $\begin{array}{c}\text { Desired Outcomes } \\
\text { (Question to be Answered) }\end{array}$ \\
\hline & & & & $\begin{array}{l}\text { Screening for Higher- } \\
\text { Order Cognitive } \\
\text { Functions }\end{array}$ & Evaluation & $\begin{array}{l}\text { Develop predictive models through } \\
\text { the identification of assessment } \\
\text { tools that take into account the role } \\
\text { of higher order functions (e.g., } \\
\text { judgment) and level of expertise }\end{array}$ \\
\hline & & & & $\begin{array}{l}\text { Screening } \\
\text { Instruments and } \\
\text { Crash Risk }\end{array}$ & $\begin{array}{l}\text { Evaluation } / \text { Validati } \\
\text { on }\end{array}$ & $\begin{array}{l}\text { Pilot test comprehensive screening } \\
\text { and track crash experience of high } \\
\text { risk vs. others }\end{array}$ \\
\hline & & & \multirow[t]{2}{*}{$\begin{array}{l}\text { Types of } \\
\text { Assessments } \\
\$ 200 \mathrm{~K}\end{array}$} & $\begin{array}{l}\text { At-Risk Driver } \\
\text { Assessment Tiers }\end{array}$ & $\begin{array}{l}\text { Screening/Assess } \\
\text { ment Development }\end{array}$ & $\begin{array}{l}\text { Develop multiple tiers of } \\
\text { assessment (e.g., self assessment } \\
\text { tools, education for medical/law } \\
\text { personnel) }\end{array}$ \\
\hline & & & & $\begin{array}{l}\text { Tools for Self- } \\
\text { Assessment }\end{array}$ & $\begin{array}{l}\text { Instrument } \\
\text { Development }\end{array}$ & $\begin{array}{l}\text { Self assessment tools for different } \\
\text { users }\end{array}$ \\
\hline & & & \multirow[t]{2}{*}{$\begin{array}{l}\text { Screening: } \\
\text { Routine or } \\
\text { focused? } \\
\$ 200 \mathrm{~K}\end{array}$} & $\begin{array}{l}\text { Evaluation of Routine } \\
\text { Screening }\end{array}$ & Evaluation & $\begin{array}{l}\text { Determine benefits/drawbacks of } \\
\text { routine screening of older drivers } \\
\text { (use randomized controlled trials) }\end{array}$ \\
\hline & & & & $\begin{array}{l}\text { Identifying At-Risk } \\
\text { Populations for } \\
\text { Screening }\end{array}$ & Case Control & $\begin{array}{l}\text { On what basis should drivers be } \\
\text { required to complete screening } \\
\text { tests? Age? Medical referral? } \\
\text { Insurance company referral? Crash } \\
\text { status? Other criteria? }\end{array}$ \\
\hline & & & \multirow[t]{2}{*}{$\begin{array}{l}\text { Referral } \\
\text { Programs } \\
\$ 100 \mathrm{~K}\end{array}$} & $\begin{array}{l}\text { Insurance Companies } \\
\text { as Partners: Referring } \\
\text { At-Risk Drivers for } \\
\text { Screening }\end{array}$ & Liaison & $\begin{array}{l}\text { Explore cooperation with insurance } \\
\text { companies. }\end{array}$ \\
\hline & & & & $\begin{array}{l}\text { Referring At-Risk } \\
\text { Older Drivers }\end{array}$ & Expert Panel & $\begin{array}{l}\text { Develop referral system for at-risk } \\
\text { drivers }\end{array}$ \\
\hline
\end{tabular}




\begin{tabular}{|c|c|c|c|c|c|c|}
\hline Votes & $\begin{array}{l}\text { Level of } \\
\text { Effort }\end{array}$ & Package & $\begin{array}{l}\text { High-priority Re } \\
\text { Sub-package, } \\
\text { where } \\
\text { applicable }\end{array}$ & $\frac{\text { earch and Implement }}{\text { Project Title }}$ & $\begin{array}{c}\text { ion Projects (conti } \\
\text { General } \\
\text { Approach/ } \\
\text { Type of Study }\end{array}$ & $\begin{array}{c}\text { Desired Outcomes } \\
\text { (Question to be Answered) }\end{array}$ \\
\hline \multirow[t]{5}{*}{7} & \multirow[t]{5}{*}{$\$ 500 \mathrm{~K}$} & \multirow[t]{5}{*}{ PI\&E } & \multirow[t]{2}{*}{$\begin{array}{l}\text { Overall } \\
\text { Awareness Level } \\
\$ 300 \mathrm{~K}\end{array}$} & $\begin{array}{l}\text { Educational Efforts } \\
\text { "Demo Project" }\end{array}$ & PI\&E & $\begin{array}{l}\text { Development of overall public } \\
\text { information strategy or social } \\
\text { marketing plan }\end{array}$ \\
\hline & & & & $\begin{array}{l}\text { Aging and } \\
\text { Transportation } \\
\text { Issues: Promoting } \\
\text { Awareness }\end{array}$ & PI\&E & $\begin{array}{l}\text { Promote awareness and education } \\
\text { on aging and transportation issues } \\
\text { and solutions - include } \\
\text { policymakers, consumers, } \\
\text { professionals, service providers, } \\
\text { health and medical, public } \\
\text { community organizations }\end{array}$ \\
\hline & & & \multirow[t]{3}{*}{$\begin{array}{l}\text { Evaluate PI\&E } \\
\text { Efforts - new and } \\
\text { old } \\
\$ 200 \mathrm{~K}\end{array}$} & $\begin{array}{l}\text { Evaluation of Mobility } \\
\text { PI\&E Resources }\end{array}$ & $\begin{array}{l}\text { Evaluate } \\
\text { PI\&E/Expert Panel }\end{array}$ & $\begin{array}{l}\text { Community-level evaluation of } \\
\text { senior mobility examine } \\
\text { materials/strategies for: } \\
\text { - appropriateness of messages and } \\
\text { delivery system } \\
\text { - cultural and geographic } \\
\text { appropriateness } \\
\text { - financial realities } \\
\end{array}$ \\
\hline & & & & $\begin{array}{l}\text { Identification of } \mathrm{New} \\
\text { Messages }\end{array}$ & PI\&E & $\begin{array}{l}\text { Identification of new messages - } \\
\text { identify successful models for other } \\
\text { social issues that can be adapted } \\
\text { and tested for senior market }\end{array}$ \\
\hline & & & & $\begin{array}{l}\text { Before You Give Up } \\
\text { Your Keys: A } \\
\text { Handbook of Options }\end{array}$ & PI\&E & $\begin{array}{l}\text { Pilot test program to make older } \\
\text { drivers and families aware of } \\
\text { options prior to loss of driving } \\
\text { privilege }\end{array}$ \\
\hline \multirow[t]{2}{*}{6} & \multirow[t]{2}{*}{$\$ 200 \mathrm{~K}$} & \multirow[t]{2}{*}{$\begin{array}{l}\text { Evaluate } \\
\text { Mobility } \\
\text { Alternatives }\end{array}$} & \multirow[t]{2}{*}{ N/A } & $\begin{array}{l}\text { Evaluation of } \\
\text { Transportation } \\
\text { Solutions }\end{array}$ & $\begin{array}{l}\text { Evaluate existing } \\
\text { programs }\end{array}$ & $\begin{array}{l}\text { Identify and evaluate successful } \\
\text { transportation solutions developed } \\
\text { in/by communities/local groups } \\
\text { (mobility options). Measure effects } \\
\text { on exposure. }\end{array}$ \\
\hline & & & & $\begin{array}{l}\text { Alternative } \\
\text { Transportation: } \\
\text { What's Working, } \\
\text { What's Not }\end{array}$ & $\begin{array}{l}\text { Literature Review/ } \\
\text { Expert Panel }\end{array}$ & $\begin{array}{l}\text { Best practices report on } \\
\text { establishing/ resolving policy issues } \\
\text { and creating funding mechanisms } \\
\text { for alternative transportation }\end{array}$ \\
\hline
\end{tabular}




\begin{tabular}{|c|c|c|c|c|c|c|}
\hline \multicolumn{7}{|c|}{ Table 1 High-priority Research and Implementation Projects (continued) } \\
\hline Votes & $\begin{array}{l}\text { Level of } \\
\text { Effort }\end{array}$ & Package & $\begin{array}{c}\begin{array}{c}\text { Sub-package, } \\
\text { where } \\
\text { applicable }\end{array} \\
\end{array}$ & \begin{tabular}{|l|} 
Project Title \\
\end{tabular} & $\begin{array}{c}\text { General } \\
\text { Approach/ } \\
\text { Type of Study }\end{array}$ & $\begin{array}{c}\text { Desired Outcomes } \\
\text { (Question to be Answered) }\end{array}$ \\
\hline \multirow[t]{2}{*}{6} & \multirow[t]{2}{*}{$\$ 2-300 \mathrm{~K}$} & \multirow[t]{2}{*}{$\begin{array}{l}\text { Mobility Alt. } \\
\text { PI\&E }\end{array}$} & \multirow[t]{2}{*}{ N/A } & $\begin{array}{l}\text { Information on } \\
\text { Mobility Alternatives }\end{array}$ & PI\&E & $\begin{array}{l}\text { Strategies to communicate mobility } \\
\text { alternatives }\end{array}$ \\
\hline & & & & $\begin{array}{l}\text { Services For Those } \\
\text { Who Stop Driving }\end{array}$ & PI\&E & $\begin{array}{l}\text { Social marketing to older people so } \\
\text { they know that they are eligible for } \\
\text { services (and to design services } \\
\text { that match their needs) }\end{array}$ \\
\hline 4 & $\$ 200 \mathrm{~K}$ & \multicolumn{2}{|l|}{$\mathrm{N} / \mathrm{A}$} & $\begin{array}{l}\text { Alternative } \\
\text { Transportation User } \\
\text { Needs And } \\
\text { Capabilities }\end{array}$ & Survey & $\begin{array}{l}\text { What are needs and capabilities of } \\
\text { alternative transportation users, } \\
\text { including pedestrians? }\end{array}$ \\
\hline 4 & $\$ 250 \mathrm{~K}$ & \multicolumn{2}{|l|}{$\mathrm{N} / \mathrm{A}$} & $\begin{array}{l}\text { Rate of Impaired } \\
\text { Status }\end{array}$ & Cohort study & $\begin{array}{l}\text { What \% of Older Drivers are } \\
\text { impaired? }\end{array}$ \\
\hline \multirow[t]{2}{*}{3} & \multirow[t]{2}{*}{$\$ 100 \mathrm{~K}$} & \multirow[t]{2}{*}{$\begin{array}{l}\text { Effects of } \\
\text { Medication on } \\
\text { Driving }\end{array}$} & \multirow[t]{2}{*}{ N/A } & $\begin{array}{l}\text { Assessment of } \\
\text { Medication Effects on } \\
\text { Older Drivers }\end{array}$ & Expert Panel & $\begin{array}{l}\text { Medication (prescription and over } \\
\text { the counter): What are the } \\
\text { connections and implications for the } \\
\text { older driver? Explore interactions } \\
\text { and combination effects, where } \\
\text { possible. }\end{array}$ \\
\hline & & & & $\begin{array}{l}\text { Effects of Medication } \\
\text { on Driving }\end{array}$ & PI\&E & $\begin{array}{l}\text { Effective dissemination of existing } \\
\text { knowledge (e.g., medication effects) }\end{array}$ \\
\hline \multirow[t]{2}{*}{3} & \multirow[t]{2}{*}{$\$ 200 \mathrm{~K}$} & \multirow[t]{2}{*}{ ITS } & \multirow[t]{2}{*}{ N/A } & $\begin{array}{l}\text { ITS and Implications } \\
\text { for At-risk Drivers }\end{array}$ & Exposure Study & $\begin{array}{l}\text { ITS Displays - HUD's, contrast, } \\
\text { maps, character size. } \\
\text { Consequences of use for exposure }\end{array}$ \\
\hline & & & & & & $\begin{array}{l}\text { Highway-related ITS devices } \\
\text { (highway) }\end{array}$ \\
\hline 3 & $\$ 100 \mathrm{~K}$ & & & $\begin{array}{l}\text { Media Portrayal of } \\
\text { Older Drivers }\end{array}$ & PI\&E & $\begin{array}{l}\text { Educate media so they frame } \\
\text { problem correctly - most older } \\
\text { drivers are safe. }\end{array}$ \\
\hline 2 & $\$ 25 \mathrm{~K}$ & & & $\begin{array}{l}\text { NPTS Survey - } \\
\text { Analysis }\end{array}$ & Expert Panel & $\begin{array}{l}\text { Identify data elements to add to } \\
\text { NPTS survey for older population } \\
\text { sample. }\end{array}$ \\
\hline
\end{tabular}




\begin{tabular}{|c|c|c|c|c|c|c|}
\hline Votes & $\begin{array}{l}\text { Level of } \\
\text { Effort }\end{array}$ & Package & $\begin{array}{c}\text { Sub-package, } \\
\text { where } \\
\text { applicable }\end{array}$ & Project Title & $\begin{array}{c}\text { General } \\
\text { Approach/ } \\
\text { Type of Study }\end{array}$ & $\begin{array}{c}\text { Desired Outcomes } \\
\text { (Question to be Answered) }\end{array}$ \\
\hline 2 & $\$ 100 \mathrm{~K}$ & . & & $\begin{array}{l}\text { Overcoming Barriers } \\
\text { to Driver Assessment }\end{array}$ & $\begin{array}{l}\text { Survey, focus } \\
\text { groups, expert } \\
\text { panel }\end{array}$ & $\begin{array}{l}\text { Overcoming barriers to seeking } \\
\text { driver assessment-both self } \\
\text { referrals and other referrals (e.g., } \\
\text { physician) }\end{array}$ \\
\hline 2 & $\$ 400 \mathrm{~K}$ & & & $\begin{array}{l}\text { Early-stage Dementia } \\
\text { Driving Behavior } \\
\text { Research }\end{array}$ & $\begin{array}{l}\text { Longitudinal } \\
\text { observational } \\
\text { study }\end{array}$ & $\begin{array}{l}\text { Early stage dementia driving } \\
\text { behavior research: Do they keep } \\
\text { driving? What are the } \\
\text { consequences? }\end{array}$ \\
\hline 2 & $\$ 1 M$ & & & $\begin{array}{l}\text { Indiana Tri-Level, } \\
\text { Update }\end{array}$ & Analyze crashes & $\begin{array}{l}\text { Repeat Indiana Tri-Level study with } \\
\text { all age groups, including at-risk } \\
\text { drivers. }\end{array}$ \\
\hline 2 & $\$ 400 \mathrm{~K}$ & & & $\begin{array}{l}\text { Medical Conditions: } \\
\text { Do They Impede } \\
\text { Insight for Self- } \\
\text { Regulation? }\end{array}$ & $\begin{array}{l}\text { Evaluate Ss, } \\
\text { conduct survey }\end{array}$ & $\begin{array}{l}\text { Some medical conditions harm } \\
\text { judgment and self-perception. } \\
\text { Investigate such conditions as } \\
\text { dementia, sleep apnea, } \\
\text { hypoglycemic reactions (e.g., in } \\
\text { diabetes), some medications. }\end{array}$ \\
\hline 1 & $\$ 200 \mathrm{~K}$ & & & $\begin{array}{l}\text { Rural Older Drivers, } \\
\text { Crashes, and } \\
\text { Exposure }\end{array}$ & $\begin{array}{l}\text { Survey, crash } \\
\text { analysis }\end{array}$ & $\begin{array}{l}\text { Do rural ODs continue to drive for } \\
\text { longer than urban or suburban } \\
\text { drivers? Is it related to a lack of } \\
\text { alternatives? If so, is this related to } \\
\text { crashes? }\end{array}$ \\
\hline 1 & $\$ 200 \mathrm{~K}$ & & & $\begin{array}{l}\text { Crashes Involving } \\
\text { Older Pedestrians }\end{array}$ & Exposure study & $\begin{array}{l}\text { Are Older Pedestrians } \\
\text { overrepresented in pedestrian } \\
\text { crashes in the U. S.? Investigate } \\
\text { exposure, looking at walking } \\
\text { exposure rather than per capita } \\
\text { rates. }\end{array}$ \\
\hline
\end{tabular}




\begin{tabular}{|l|l|l|}
\hline \multicolumn{2}{|c|}{ Medium-priority Research and Implementation Projects } \\
\hline \multicolumn{1}{|c|}{ Project Title } & \multicolumn{1}{|c|}{$\begin{array}{c}\text { General Approach/ } \\
\text { Type of Study }\end{array}$} & \multicolumn{1}{c|}{$\begin{array}{c}\text { Desired Outcomes } \\
\text { (Question to be Answered) }\end{array}$} \\
\hline $\begin{array}{l}\text { Passengers of Older Drivers: } \\
\text { Distraction or Assistant? }\end{array}$ & $\begin{array}{l}\text { Investigate performance of ODs with } \\
\text { passengers, particularly spouses. Assess } \\
\text { performance in simulator while } \\
\text { unassisted/assisted by spouse. May } \\
\text { compare to middle-age drivers and/or } \\
\text { inexperienced drivers. }\end{array}$ & $\begin{array}{l}\text { Do older couples use each other as external working } \\
\text { memory sources when driving? Unlike teens with } \\
\text { passengers, ODs with spouse-passengers may have } \\
\text { lower crash rate. } \\
\text { What are the consequences? What are the limitations? }\end{array}$ \\
\hline $\begin{array}{l}\text { Crash rates of Older Females: } \\
\text { Cohort Effect? }\end{array}$ & Expert Panel & $\begin{array}{l}\text { Examine higher crash rate for older females (Gender X } \\
\text { Age interaction) }\end{array}$ \\
\hline Medical Advisory Boards & $\begin{array}{l}\text { Examine role of medical advisory boards in relation to at- } \\
\text { risk drivers. Develop series of standards to apply. }\end{array}$ \\
\hline
\end{tabular}




\section{PROBLEM STATEMENTS}

Problem statements have been generated for each High-Priority project. Problem statements give a Title, Problem, Objective/s, Related Work, and Cost for each project.

Title:

Problem:

Objective:

Related Work: Continuation of pilot program initiated in 1996.

\section{Maryland Model: Further Testing} further testing and refinement. be incorporated into follow up projects. continue to drive. jurisdictions.
NHTSA, in cooperation with the State of Maryland, is currently pilot testing a Model Driver Screening and Evaluation Program (DTNH22-96-C-O5140). This study examines retrospective and prospective relationships between performance on a battery of functional screening measures and indices of driving safety and mobility, for varying samples of older drivers. A volunteer-renewal sample, a residential living community sample, and a medical referral sample were obtained and examined using a NHTSA-developed Gross Impairments (GRIMPS) screening tool, plus other assessment procedures. A preliminary indication of Model Program validity as well as its administrative feasibility in diverse settings will be reported at the project's conclusion in 2001, and a test plan containing recommendations for replicating components of the model in other states will be produced. A follow-up would allow

1) Follow-up projects in one or more states should provide more extensive tests of the validity and feasibility of the screening and assessment procedures which appear most promising in the Maryland pilot. Where problems were encountered in the Maryland pilot, corrective approaches should be evaluated. Where the Maryland pilot indicated a need for additional procedures which were beyond the scope of that study, these could

2) Efforts should be included to disseminate information to the public, including health care and other elder care practitioners; to encourage physician reporting where other interventions have failed; to facilitate the formation or improve the effectiveness of Medical Advisory Boards; to integrate assessment with mobility counseling activities, and to assist with the transition to other transportation options for those who do not

3) The final product should be a fully operational program that can be exported to other

Cost: $\quad \$ 500 \mathrm{~K}$ 
Title:

\section{Law Enforcement Program: Detecting Impaired Drivers}

Problem: $\quad$ Although law enforcement officers routinely encounter drivers whose abilities may be impaired, no standard program or procedure exists to help officers handle the situation. Current procedures are designed to address alcohol- or drug-impairment and do not adequately handle cognitive or physical impairment. In addition, informal cultural pressures discourage referral of drivers when they are not substance-impaired. However, non-substance-impaired drivers can be just as hazardous as drunk or drugged drivers. When policies do address cognitive or physical impairment, they often merely suggest calling for medical assistance (an option which is often used only in acute cases, such as a driver who cannot give his/her name or cannot walk). Law enforcement officers should be provided with a procedure to handle cognitively-and/or physically-impaired drivers.

It is important that input be solicited from the law enforcement community. Procedures and criteria must be usable by law enforcement officers. It is strongly recommended that a current or former law enforcement officer/s be involved at every stage of the development process.

Objective: $\quad$ 1) Develop and validate a training curriculum for law enforcement officers to spot impaired drivers and provide a referral for assessment. Criteria for referral must be based on driver behavior, not age or other demographic characteristics. Consider developing a checklist and referral form for officers to keep in car.

2) Provide and/or simplify referral avenue.

Related Work: Law-enforcement officer-based detection programs for alcohol \& drug-impaired drivers, Older Driver Cues for Law Enforcement

Cost: $\quad \$ 2-300 \mathrm{~K}$ 


\section{Title:}

Problem:

Objective:

\section{Related Work:}

Cost:

\section{Driver Retraining Evaluation}

Driver retraining programs (e.g., improvement or refresher courses) are increasing in number and popularity. No definitive evaluation has been made of assessment and/or retraining programs for older or at-risk drivers. It is essential to establish whether or not such programs reduce crash risk.

1) Conduct follow-up studies to evaluate the safety outcomes of assessment-andretraining programs. Include driver remediation programs.

2) Examine crash rates (and/or conflicts) to measure safety outcomes. Approach should take into account self-selection bias (i.e., drivers who are concerned with safety may be more likely to enroll in such programs; drivers who fear being told they should cease driving may be less likely to enroll). Approach should also consider the type of retraining program (e.g., those which involve no driving component, those with simulators, etc.) Approaches to be considered might include diary study or survey.

\section{Driver retraining programs for accident-involved drivers and frequent} offenders, 55ALIVE

\section{$\$ 400 K$}


Title: Driver Retraining Standards: Standardization of Training and Standards of Driver Rehabilitation/Assessment Professionals

Problem: If driver re-training proves effective in "Driving Retraining Evaluation" then it is beneficial to define the issues involved in maximizing the effectiveness of training programs and of driver rehabilitation/assessment professionals.

Objective: $\quad$ 1) Use an expert panel to identify research issues involved in potential standardization of training and standards of driver rehab/assessment professionals. These issues might include the educational background/credentials of the trainer, the format of the training (e.g., written materials, lecture, video, simulator, on-road), the material covered (e.g., visual attention, compensating for reduced abilities, exercises to increase range of motion, self-regulation, defensive driving strategies, when to stop driving, etc.) preand post-testing, continuing monitoring of safety outcomes, etc.

2) Produce list of potential research issues. Include rationale and possible ramifications of each issue.

Related Work: Driver training program standards

Cost: $\quad \$ 100 \mathrm{~K}$ 


\section{Title: Screening and Assessment: Development, Evaluation and Validation of Tools}

Problem: $\quad$ Screening instruments are needed to measure drivers for problems related to crashes. Traditional, one-to-one driving examinations are not financially feasible on a large scale. Therefore, screening instruments are needed to select those individuals who are most likely to have higher crash risk.

Objective: $\quad$ 1) Develop and evaluate, then implement, screening tests for visual, cognitive and/or physical problems related to crashes. Include higher-order functions (e.g., judgment) and level of expertise, and develop predictive models.

2) Develop test training materials for administrators.

3) Pilot test comprehensive screening and track crash experience of high-risk drivers vs. others.

Related Work: GRIMPS, driver training assessment tools, graduated licensing work

Cost: $\quad \$ 300 \mathrm{~K}$ 
Title:

Problem:

Objective:

Cost:
Related Work: GRIMPS, driver training assessment tools, AAA and New York State

\section{Screening and Assessment: Types/Tiers of Assessments}

Individuals who interact with older adults (and the older adults themselves) are often concerned about driving abilities. They wish to ensure that the older adult is safe on the road, but have few resources to find out whether this is the case. Screening and assessment instruments are needed for use by people in different roles. Individuals, family members, social workers, physicians, and others would benefit from tools geared toward different users. These tools would allow users to gauge the safety of the older driver and provide objective evidence for discussion and (possibly) intervention. This would allow drivers to continue for as long as safely possible; while assisting in the cessation of drivers for whom safe driving is not possible.

Develop multiple tiers of assessment for different types of users (e.g., individuals, family members, social workers, occupational therapists, medical personnel). Include selfassessment. May use results from Screening and Assessment: Development, Evaluation and Validation of Tools as input. Guides (particularly for family members and physicians) should emphasize that age is not the determinant of safety: physical and cognitive abilities are far more important. Tools should be developed with an eye to enhancing interactions with the older adult and improving the safety of all road users. materials

$\$ 200 K$ 
Title: Screening and Assessment: Screening - Routine or Focused?

Problem: $\quad$ Routine screening of all drivers would be impractical. Even the least expensive screening methods will involve some cost, and a blanket screening would be exorbitantly expensive in both dollars and time. If higher-risk populations can be identified for screening, focused screening might be more efficient and more likely (per screening) to expose unsafe drivers. By screening the right populations, safety can be maximized and cost minimized.

Objective: $\quad$ 1) Evaluate routine screening to determine benefits/drawbacks of routine screening of older drivers (use randomized controlled trials).

2) Identify at-risk populations for screening. Define criteria for requiring drivers to complete screening tests. Consider using criteria such as extreme age, medical referral, insurance company referral, crash status, plus other criteria. Use case control methodology.

Related Work: Screening efforts to identify at-risk young drivers and alcohol-impaired drivers

Cost: $\quad \$ 200 K$ 
Title:

Problem:

Objective:

Related Work:

Cost:

\section{Screening and Assessment: Referral Programs}

In order to make screening available to at-risk drivers, a referral system must be developed. Current referral systems are slow (often taking 30 days or more) and referral criteria are often not keyed to the wide possible range of cognitive and physical impairments.

1) Using an expert panel, develop referral system for at-risk drivers. Assume that referrals will come from diverse sources (e.g., health care providers, law enforcement, family members, etc.) Assume that impairment may be caused by a wide variety of cognitive and/or physical impairment.

2) Liaise with insurance companies to explore cooperation in referring at-risk drivers for screening. Consider other possible liaison sources.

Maryland Model, other assessment/referral efforts to target other at-risk populations

$\$ 100 \mathrm{~K}$ 
Title:

PI\&E: Overall Awareness Level

Problem: $\quad$ There is very little (accurate) awareness in the general population of the issue of aging and transportation issues. For example, portrayals in the media tend to assume that old age alone creates unsafe driving - that any older driver is a bad driver, and that older people ought not to drive. In addition, popular culture tends to assume that older people do not self-regulate: that is, that their licenses or keys must be "taken away" when they are "too old to drive".

Objective: $\quad$ 1) Promote awareness and education on aging and transportation issues and solutions - include policymakers, consumers, professionals, service providers, health and medical, public community organizations.

2) Define desired behavioral outcomes for identified target groups.

3) In a demo program, develop overall public information strategy or social marketing plan.

4) Evaluate for changes in previously-identified behaviors (e.g., number of requests for mobility information, number of licenses turned in, requests for assessment, etc.)

Related Work: Other NHTSA work re restraint systems, car seats, etc.

Cost: $\quad \$ 300 \mathrm{~K}$ 
Title:

Problem:

Objective:

\section{PI\&E: Evaluate PI\&E Efforts - new and old}

Drivers and non-drivers must be informed about their options. An evaluation of existing messages will enhance the development of new messages and delivery systems.

1) Conduct a community-level evaluation of mobility for non-drivers. Examine materials/strategies for:

- appropriateness of messages and delivery system

- cultural and geographic appropriateness

- financial realities

2) Identify successful models for other social issues (e.g., public health) that can be adapted and tested for senior market.

3) Identify desired behavioral outcomes.

4) Identify new messages. Pilot test program to make older drivers and families aware of options prior to loss of driving privilege and produce a document, "Before You Give Up Your Keys: A Handbook of Options". Evaluate behavioral outcomes.

Related Work: Other NHTSAFHWA and DOE efforts to promote bicycling \& walking as mobility options

Cost: $\quad \$ 200 \mathrm{~K}$ 
Title:

Problem:

Objective:

.ronge:

Related Work:

Cost:

\section{Evaluate Mobility Alternatives}

It is strongly suspected (see Rural Older Drivers, Crashes and Exposure study) that drivers who do not have alternative transportation continue to drive for longer than they know is safe, simply because they feel they have no choice. Conversely, drivers who have alternative methods of transportation may reduce their driving or cease driving earlier than if those alternatives were not in place. Alternative transportation may increase safety by reducing the numbers and exposure of impaired drivers. Mobility alternative programs differ greatly by locality, and much can be learned by examining existing programs.

1) Conduct a literature review and identify existing mobility alternative programs.

2) Evaluate existing programs.

3) Identify successful transportation solutions developed in/by communities/local groups (mobility options).

3) Produce a Best Practices report. Conduct an expert panel if needed to produce the report. Cover issues of establishing/ resolving policy issues and creating funding mechanisms for alternative transportation.

Evaluation of effect of ADA on increases in mobility/access, NIDR efforts, Beverly Foundation study of unusual mobility programs

$\$ 200 K$ 


\begin{abstract}
Title:
Problem:

\section{Mobility Alternatives PI\&E}

If transitioning or non-drivers are to take advantage of mobility alternatives and reduce exposure to crashes, they must be informed about their options. If transitioning drivers are aware of mobility alternatives, they may choose to drive less; they may also choose to cease driving earlier than they otherwise might. Effective communication of mobility options is needed.
\end{abstract}

Objective: $\quad$ 1) Define behavioral goals (e.g., increased use of mobility services, reduced driving)

2) Develop strategies to communicate mobility alternatives

3) Develop social marketing to older people so they know that they are eligible for services (and to design services that match their needs)

4) In a pilot or demo, measure behavioral change

Related Work: Other PI\&E evaluations re seat restraints, car seats, etc. NIDR efforts

Cost: $\quad \$ 250 \mathrm{~K}$ 
Title: $\quad$ Alternative Transportation Users: Needs And Capabilities

Problem: In order to ensure that unsafe drivers do not continue to drive, alternative transportation must fulfill the needs of its potential users. It is necessary to define the needs and capabilities of the target population. If alternative transportation is useful and usable by the target population, drivers may voluntarily reduce their number of trips taken and perhaps be willing to stop driving sooner. Crash risk will then be lowered, through both the reduction in exposure and by the reduction specifically of impaired driving.

Objective: Use a survey to identify the needs and capabilities of alternative transportation users. Include pedestrians. Issues should include physical and cognitive challenges (see Literature Review, Appendix 1 for lists); users' ability (or inability) to get to a common pick-up point; proximity to public transportation of likely destinations (e.g., medical center, retail stores, senior center, etc.); the need to accommodate devices such as canes, walkers, wheelchairs, etc.

Related Work: FHWA older driver/pedestrian research, NIDR efforts

Cost: $\quad \$ 200 K$ 


\section{Title:}

Problem:

Objective:

Related Work:

Cost:

Note:

\section{Rate of Impaired Status}

Older drivers are stereotyped by popular culture as incapable of driving safely. This is inaccurate. Although it is clear that SOME older people can no longer operate a vehicle safely, it is unknown what proportion of the older driving population is unsafe.

Determine the proportion of Older Drivers who are safe/unsafe.

1) Select assessment tool/s and carefully investigate cutoff point or range to define "safe" and "unsafe".

2) Administer assessment tool/s to a sample of the older driving population and to a sample of younger drivers.

Special attention must be paid to issues of sampling and self-selection. Sample must be representative of the older driving population regarding such issues as sex, age, visual acuity, medication use, physical limitations (or lack thereof), etc. A younger sample must be included for comparison purposes.

Standards development, driver task analyses, Human Resources Research Organization (HumRRO) task analyses and HumRRO efforts to develop links between operator tasks and human performance skills and capabilities

\section{$\$ 250 \mathrm{~K}$}

The above project is difficult. The selection of a cutoff point or range to define "safe" and "unsafe" is particularly problematic. If assessment scores and crash rates are plotted together, it is extremely unlikely that a neat step function will appear (which would make a cutoff point self-evident). Instead, researchers may find themselves investigating changes in slope, breaks in a curve, or other even more difficult functions. Effort applied to Objective 1 should not be minimized. 
Title:

Problem:

Objective:

Related Work:

Cost:

\section{Assessment of Medication Effects on Driving}

Much of the Older Driver population uses prescription and over-the-counter medications, singly and in combination. In 1988, people over age 65 comprised $12 \%$ of the population but accounted for $29 \%$ of all prescriptions (Ray, Thapa \& Shorr, 1993). $80 \%$ of them were taking at least one medication. Approximately $21 \%$ of $65-84$ year olds were taking a medication that might impair driving (e.g., benzodiazepine, antidepressant, opioid, antihistamine, etc.) It is important that individuals be aware of possible side effects that may impact on the driving task.

1) Medication (prescription and over the counter): Conduct an expert panel of physicians and other medication specialists. Define the connections and implications of medicine use for the older driver. Explore interactions and combination effects, where possible. Identify gaps in knowledge about these effects to suggest needed research.

2) Develop PI\&E materials for effective dissemination of knowledge of medication effects.

Alcohol/drug impaired driver research efforts

\$100K 
Title:

Problem:

Objective:

Related Work:

Cost:

\section{ITS and Implications for At-Risk Drivers}

Burgeoning ITS technology has made its way to the user market. Use of ITS instruments may improve performance (especially when users are familiar with the system) or may complicate the driving task. Effects of use on exposure are unknown (e.g., if ITS increases drivers confidence, they might change their trip frequency or length; with vision enhancement systems drivers might increase night trips; and adaptive cruise control users might increase their long-distance driving.) Real-life application may have unintended consequences.

1) Investigate Older Driver use of ITS systems. Examine instances when ITS might enhance safety, and whether (or when) it might instead complicate the driving task or cause a distraction.

2) Study interface issues of ITS displays with an eye to an aging population (e.g., HUD's, contrast, maps, character size.)

3) Determine consequences of use for exposure. Specifically, determine if ITS technology might encourage at-risk drivers to increase their miles drives/trips taken and thereby increase their exposure.

FHWA and NHTSA ITS work

$\$ 200 \mathrm{~K}$ 
Title:

Problem:

Objective: 


\section{Title: $\quad$ National Personal Transportation Survey (NPTS) - Analysis}

Problem: $\quad$ The NPTS survey addresses many important issues, but does not investigate issues of aging in detail. The identification of additional data elements for the NPTS survey would be beneficial to the state of knowledge regarding older individuals' transportation, and to NHTSA's research efforts on at-risk drivers. In addition, the sample size of drivers over 85 needs to increase to a level that would allow generalizability.

Objective: $\quad$ 1) Use an expert panel to identify data elements to add to NPTS survey for an older population sample. Useful elements might include indicators of health and cognitive/physical function; day and night driving; frequency of driving; modifications being taken; crashes, violations, near misses, getting lost or difficulty navigating; use of alternate transportation; desire to stop driving.

2) Request increase in sample size of older drivers, particularly $85+$ age group.

Related Work: Previous NPTS work, efforts to improve NPTS coverage of pedestrian/bicycling activities

Cost: $\quad \$ 25 K$ 
Title:

Problem:

Objective:

1) Use a survey, focus groups, and/or an expert panel to define barriers to seeking assessment. Study both self-referrals and other referrals (e.g., physician).

2) Make recommendations regarding solutions to barriers.

Related Work: Efforts to overcome resistance to screening for medical conditions (e.g., breast \& prostate cancer)

Cost: $\quad \$ 100 \mathrm{~K}$ 
Title:

Problem:

Objective:

\section{Early-Stage Dementia Driving Behavior Research}

Many of those diagnosed with early stage dementia continue to drive. Although the diagnosis itself does not necessarily indicate hazardous driving, the short- and longterm consequences are unclear. The resistance of later-stage dementia patients to driving cessation is especially troubling.

1) Conduct a longitudinal observational study of early stage dementia patients.

2) Measure the proportion of patients with early stage dementia who keep driving.

3) Measure exposure and crash rates and/or near misses.

Related Work: Work by NIMH, NIH

Cost: $\quad \$ 400 \mathrm{~K}$ 
Title:

Problem:

Objective:

Related Work:

Cost:

\section{Indiana Tri-Level, Update}

The Indiana Tri-Level studies were in-depth investigations of specific crashes. The study included on-site data collection (skid marks, coefficients of friction, surface characteristics) as well as detailed psychological analyses/profiling of the crashinvolved. An update including all age groups would be invaluable and would shed light on many crash-related questions, such as those involving medication use, vulnerability to distraction, speed differentials, visual acuity, cognitive and physical limitations, etc. Although many of these are believed to have safety-related outcomes, some relationships are hard to establish (or disprove) based on current data. In-depth investigations would provide the power and breadth of data necessary to directly establish (or disprove) relationships between many age-related issues and crashes.

1) Conduct additional in-depth investigations with all age groups, including Older Drivers.

2) Analyze crashes, using hard-copy crash reports and site visits. Use caution when attributing "fault", avoiding age bias. Investigations should include (but not be limited to) medication use, vulnerability to distraction, speed differentials, visual acuity, cognitive and physical limitations, etc.

3) Use case control approach to determine overinvolvement associated with factors such as medication use and/or cognitive and physical limitations. Otherwise, the study might simply measure prevalence of that factor in the population and would not show impact on crash risk.

In-depth investigations on pedestrian injury causation parameters by NHTSA, original Indiana Tri-Level

\section{$\$ 1 M$}




\section{Title: Medical Conditions: Do They Impede Insight for Self-Regulation?}

Problem: $\quad$ Some medical conditions (e.g., dementia, sleep apnea, hypoglycemic episodes or insulin reactions, some medications) harm judgement and self-perception. Because judgement and self-perception are critical for self-regulation, self-regulation may be less effective. That is, the same condition that creates a hazardous driving state prevents the driver from recognizing the danger.

Objective: 1) Target specific medical conditions which may affect judgement and self-perception, thereby potentially interfering in self-regulation. Consider studying dementia, sleep apnea, hypoglycemic reactions (e.g., in diabetes), some medications (e.g., antihistamines).

2) Design method to evaluate subjects and conduct survey to determine whether the targeted medical conditions impede self-regulation.

Related Work: $\quad$ NIMH, NIH work

Cost: $\quad \$ 400 \mathrm{~K}$ 
Title: $\quad$ Rural Older Drivers, Crashes, and Exposure

Problem: $\quad$ Rural Older Drivers have few alternative transportation solutions upon driving cessation. Older Drivers may continue to drive for longer than their urban counterparts. If so, this may be because of lack of alternative transportation methods and/or a lack of nearby services. If Older Drivers do drive longer, crash rates may be affected. Because rural driving involves less traffic and fewer complex driving situations, crash rates might be lower or the same as for urban drivers. Conversely, rural driving often involves greater distances and higher speeds, so crash rates might be higher than for urban counterparts.

Objective: $\quad$ 1) Define rural drivers as those whose residence is outside a Standard Metropolitan Statistical Area (SMSA).

2) Compare rural drivers to urban drivers. Do not include suburban drivers in either sample, as suburbs vary greatly in their characteristics (e.g., access to mass transit or other alternative transportation, distance to necessary services, traffic density, etc.)

3) Conduct a survey (or diary study) and crash analysis to determine exposure and crash rate of rural older drivers compared to urban. Investigate relationship to crashes. Measured variables should include (but not be limited to) number and distance of trips taken, alternative transportation methods, self-perceived driving efficacy, and other necessary information.

Related Work: ITS work targeting rural areas/driving

Cost: $\quad \$ 200 \mathrm{~K}$ 


\section{Title: Crashes Involving Older Pedestrians}

Problem: Older Pedestrians are strongly represented in pedestrian fatalities, particularly at intersections. However, their level of exposure is unknown, so any estimated rate is pure speculation. That is, it is unknown whether older pedestrians make up a greater proportion of the pedestrian population (which would increase their representation in crashes), or if they do more walking than younger pedestrians (which would also increase their representation in crashes) or if older pedestrians are more at risk when walking than are younger pedestrians.

Specific issues involving older pedestrian crashes are also in need of study and might be addressed. For example, older pedestrians appear to be overinvolved at intersections, but older pedestrians might be more likely to cross at the intersection than younger pedestrians, thereby inflating exposure to intersections relative to younger pedestrians. Additionally, intersection crashes might exist disproportionately at complex intersections. Older Pedestrians might be overrepresented in right turn on red (RTOR) crashes. It has long been believed that short pedestrian "WALK" signals might be related to fatalities in older pedestrians, but this has not been directly demonstrated. Investigate length of "WALK" signals to see if the "older-pedestriantrapped-by-the-light" issue is verifiable.

Objective: Determine whether Older Pedestrians are overrepresented in pedestrian crashes in the U.S.

1) Collect pedestrian exposure data. Possible methods might include diaries, videotapes, surveys, telephone surveys, site observation, etc.

2) Consider investigating specific crash types (e.g., intersection issues including RTOR, length of "WALK" signals, etc.) In-depth crash case studies might be necessary to investigate types of crashes.

Related Work: FHWA pedestrian exposure studies, NHTSA pedestrian exposure methodological efforts

Cost: $\quad \$ 200 \mathrm{~K}$ 
A Problem statement has been generated for a medium-priority project.

Title: $\quad$ Crash Rates of Older Females: Cohort Effect?

Problem: $\quad$ Some data indicates a Gender X Age interaction for crash rates of drivers (Smiley, MacGregor, Chipman, Taylor \& Kawaja, 1997; Smiley, Lee-Gosselin, Chipman \& MacGregor, 1991). That is, Older female drivers may have a higher crash rate (per million driver kilometers per year) than Older male drivers, while no such effect is found in younger ages. This may be a cohort effect (i.e., specific to the current Older generation and not applicable to aging baby boomers), or might be a unique effect of aging on females that impacts the driving task, or might be caused by some other factor.

Objective: Investigate Gender X Age interaction.

1) Identify possible crash predictors. Consider many possible influences such as years of driving experience, change in type of driving (e.g., changing from local, residential driving to limited-access highways), an increase in responsibilities that may cause fatigue (e.g., caring for infirm spouse), etc.

2) Measure relationship of predictors to crash rates. Use caution to ensure an adequate sample size.

Related Work: Crash research on over-involved young male drivers/cohort effects

Cost: $\quad \$ 125 K$

Note: $\quad$ NHTSA might explore the possibility of supplying data to the TRB Committee on Women's Issues in Transportation for investigation of this issue. 


\section{PRIORITIZATION}

Three possible prioritization schemes have been developed. All of them assume level funding at $\$ 500 \mathrm{~K}$ per year, spread over seven years. Each prioritization scheme uses slightly different priorities and differs from the others in the exact studies funded.

Each prioritization scheme is illustrated with a Gantt chart, which presents a timeline and funding levels for the projects over the 7-year span. Arrows show which projects depend on the results of others. Numbers under each timeline show funding per year for each project.

The Strict Vote-based Prioritization strictly followed the votes given by the Expert Panel votes were cast on the basis of safety urgency, practicality and feasibility). Projects which received the most Expert Panel votes were assigned the highest priority. The Strict Vote-based Prioritization, therefore, is driven entirely by the votes cast by the Expert Panel.

The Diversification Strategy gave greater emphasis to the cost of individual projects. In order to diversify the investment in different research areas, lower-cost projects, from a wider range of topic areas, received higher priority. Overlapping topic areas were limited. If two projects addressed the same topic area, the less-expensive project was recommended. In this way, investment was spread out among as many investigations as possible.

The Topic Coverage Prioritization examined high-priority project in terms of topic coverage. This scheme maximizes coverage of high-priority topic areas, with a special emphasis on feasibility. Overlap of topics is minimized, but with attention paid to the topic coverage rather than price tag. That is, when two projects might have overlapped in the topic, the one providing greater coverage (either in a wider range or in terms of greater depth) was recommended. 


\section{STRICT VOTE-BASED PRIORITIZATION}

Prioritization strictly followed the votes given by the Expert Panel (votes were cast on the basis of safety urgency, practicality and feasibility). The top-voted projects were assigned highest priority. As shown in Table 3, the projects are spaced out through the 7-year time frame, re-divided into subpackages and individual studies. The Table is in Gantt chart format and shows the funding level and timeline of each study. 
Table 3

Timeline for Strict Vote-Based Prioritization

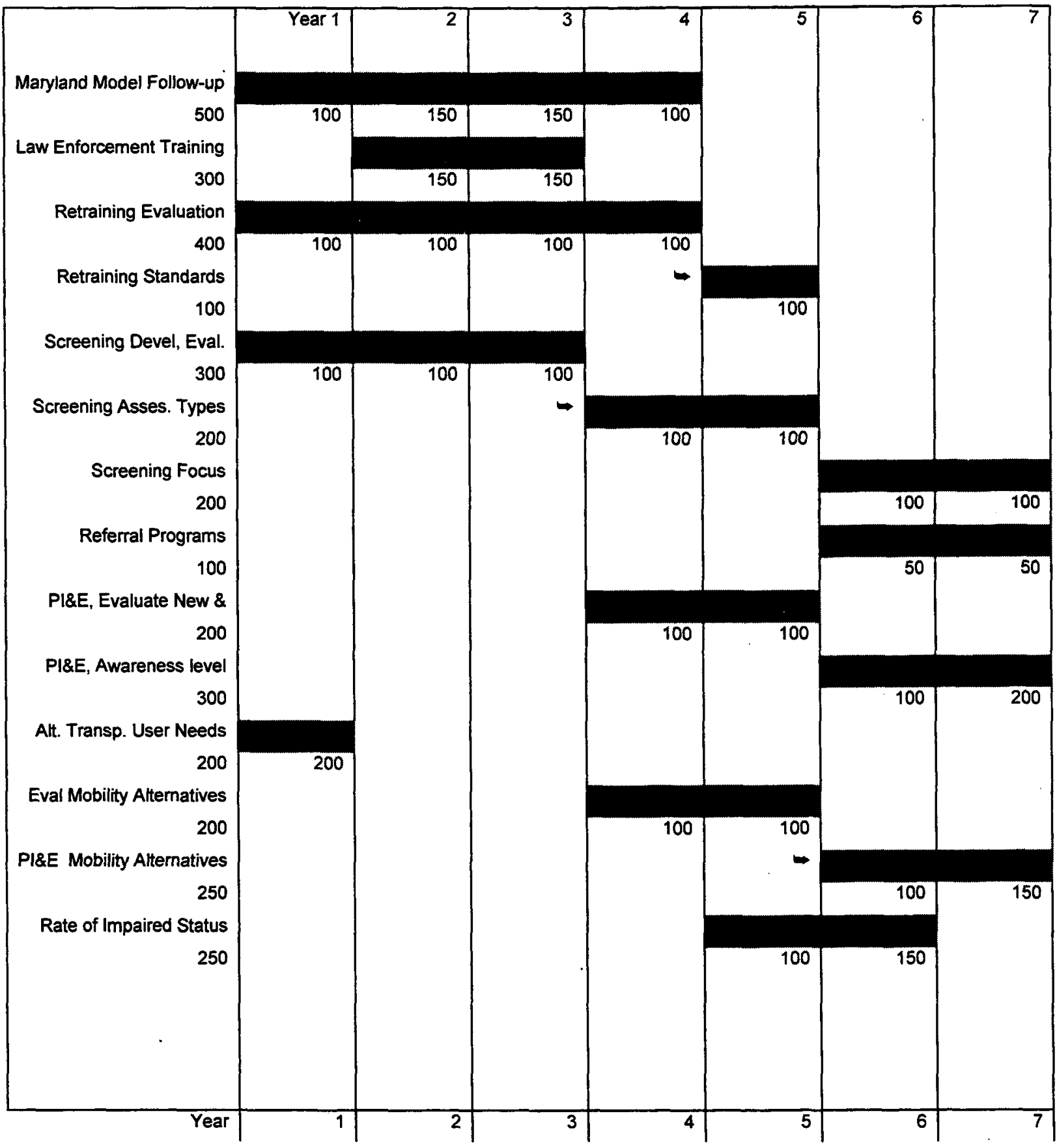




\section{DIVERSIFICATION STRATEGY}

The cost of individual projects was examined and was given weight in this prioritization scheme. If prioritization were to be assigned predominantly to very large projects, given budget limitations, a single expensive project might tie up all available resources in a calendar year. This limits the type of outcomes produced. In order to diversify the investment in research areas, lower-cost projects, from a wider range of topic areas, were assigned a higher priority in Table 4.

In order to spread out the investment, overlapping topic areas were limited. If two projects covered the same topic area, the less-expensive project was recommended.

For example, the Maryland Model Follow-up addresses many of the same issues as the Screening/Assessment projects - plus it already has a good deal of the infrastructure in place for investigation and follow-up. It may be limited in its ability to generate new instruments; but because the project is testing GRIMPS (a screening instrument developed for NHTSA), it may be wise in any case to let those results arrive before investing heavily in a different instrument. Whether results uphold the current model or point to necessary modifications, the next effort should attempt to maximize the return on those results.

It is clear that a greater number of projects is funded in this current approach: giving up any very large project enables the funding of several smaller programs.

A small project was needed to round out the funding in this scheme. A single Medium-priority project was recommended for funding in this prioritization scheme. "Crash Rates of Older Females", an investigation of the Gender X Age crash rate interaction was recommended for funding at $\$ 125 \mathrm{~K}$. 
Table 4

Timeline for Diversification Strategy Prioritization

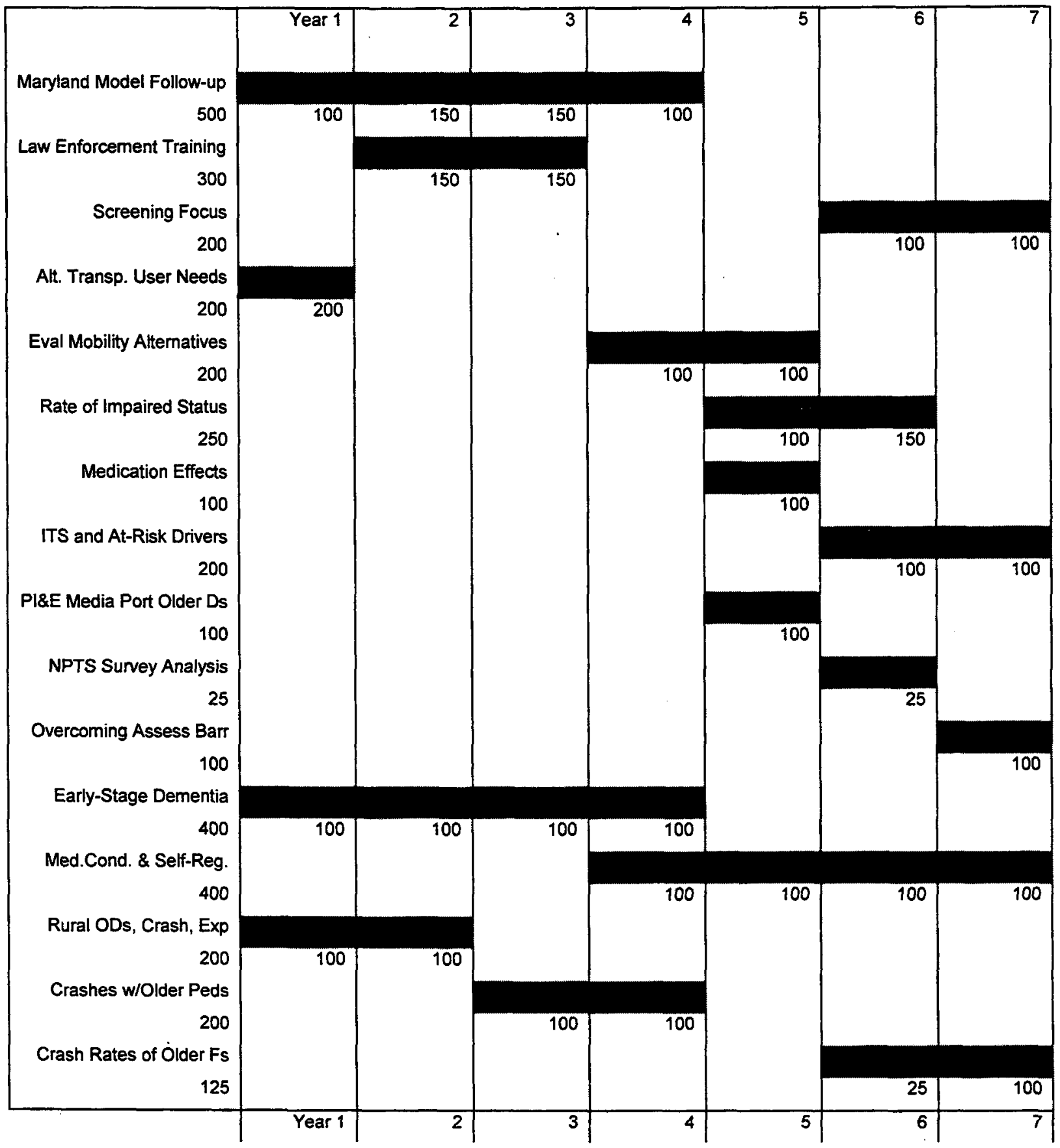




\section{TOPIC COVERAGE PRIORITIZATION}

In this prioritization scheme, high-priority projects have been examined with an eye to topic coverage. This scheme is intended to maximize coverage of high-priority topic areas, with a special emphasis on feasibility. Overlap of topics is minimized, but with attention paid to topic coverage rather than price tag (see Table 5).

Again, the Maryland Model Follow-up and the Screening/Assessment projects overlap in their emphasis. Again, the Maryland Model Follow-up is recommended for funding rather than the entire Screening/Assessment package, but a subset of the Screening/Assessment packages have been recommended where there is less overlap with the Maryland Model.

In general, less emphasis has been placed on retaining multi-study packages in their entirety. Where subpackages or individual studies assist in topic coverage, they are "folded back out" and assigned to the timeline.

The study on the "Rate of Impaired Status" is not recommended here for funding. Although the identification of the impaired population proportion is a laudable goal, there are serious challenges in terms of feasibility. Without a valid instrument to define "fitness" to drive, the measurement of this issue is impossible.

Other projects address the development of instruments to measure "fitness" to drive (screening tools and assessments). During the course of reliability and validation testing, the proportion of the population scoring as "unfit" should be revealed. It is recommended that this phase be made explicit in the funding of screening/assessment (specifically, in the Maryland Model Follow-up), and that a separate project not be funded to address this goal.

The "ITS and Implications" study has not been recommended for funding in this prioritization. Although it is important to determine the effects of ITS technology use, a portion of the ITS literature already contains older and younger samples. It is far more efficient for studies to include an older sample than it is to fund an entirely separate project exclusively devoted to age effects. 
Table 5

Timeline for Topic Coverage Prioritization

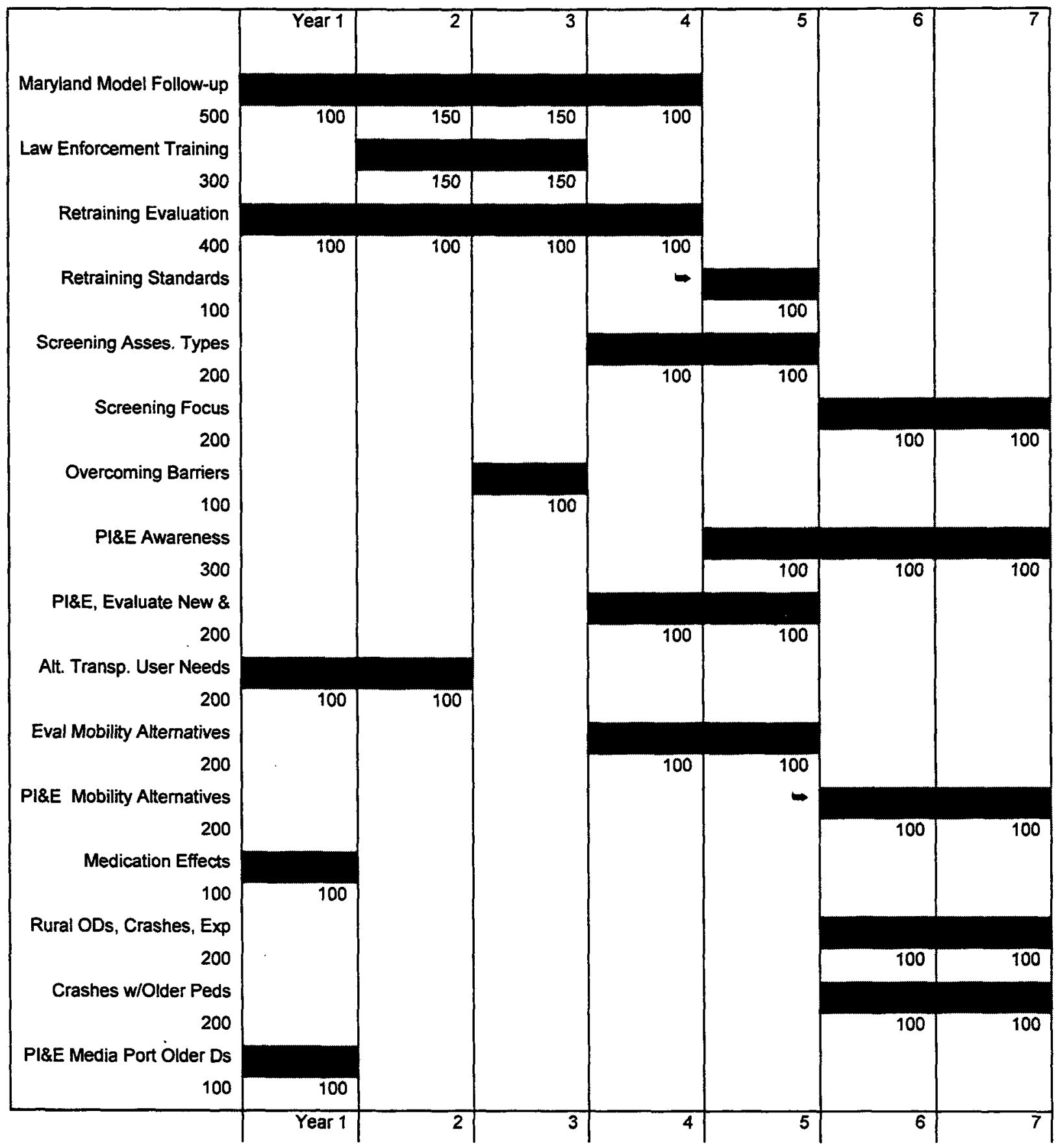




\section{REFERENCES}

AAA Foundation for Traffic Safety, "How to Help an Oider Driver, A Guide for Planning Safe Transportation," Washington, DC, 2000.

Anderson, J. R. "Rules of the mind." Hillsdale, New Jersey: Erlbaum, 1993.

Caird, J. K., "In-Vehicle Intelligent Transportation Systems (ITS) and OIder Drivers' Safety and Mobility," Draft, Cognitive Ergonomics Research Laboratory Department of Psychology, University of Calgary, Calgary, Canada, In Preparation.

Cerelli, E., Older drivers: The age factor in traffic safety. NHTSA Technical Report, DOT HS 807-402, 1989.

Craik, F. I. M., "Age Differences in Human Memory." In: J. E. Birren and K. W. Schaie (eds.) Handbook of the Psychology of Aging. van Nostrand Reinhold: New York, NY, 1977.

Diller, E., Cook L., Leonard, D., Reading, J., Dean, J.M. and Vernon, D., "Evaluating Drivers Licensed with Medical Condition in Utah, 1992-1996," DOT HS 809 023, Contract No. DTNH22-96-H59017 Modification 0002, National Highway Traffic Safety Administration, Washington, DC, June 1999.

Evans, L. Older driver involvement in fatal and severe traffic crashes. Journal of Gerontology, 43:S18693, 1988.

Fildes, B. (1997). "Safety of Older Road Users", Draft, Monash University Accident Research Centre, Victoria, Australia.

Hakamies-Blomqvist, L., 'Safety of Older Persons in Traffic: Recent Development in Older Road Users' Safety," Transportation in an Aging Society: A Decade of Experience, Conference Proceedings, Transportation Research Board, Washington, DC, In Preparation.

Hakamies-Blomqvist, L., "Compensation in Older Drivers as Reflected in Their Fatal Accidents." Accident Analysis and Prevention, 26(1), pp. 107-112, 1994.

Just, M. A., and Carpenter, P. A. "A capacity theory of comprehension differences in working memory," Psychological Review, 99, pp. 122-149, 1992.

Kanouse, D. E., "Improving Safety for Older Motorists By Means of Information and Market Forces," chapter in Transportation in an Aging Society, Volume 2, Transportation Research Board, 1988.

Kerschner, H. and Aizenberg, R., "Transportation in an Aging Society Focus Group Project, Appendix: Summary of Results by State", Beverly Foundation, Pasadena, CA, November 1999.

Kerschner, H. and Aizenberg, R., "Transportation in an Aging Society Focus Group Project," Beverly Foundation, Pasadena, CA, November 1999.

Knoblauch, R. L., Nitzburg, M., Reinfurt, D., Council, F., Zegeer. C., and Popkin, C., "Traffic Operations Control for Older Drivers," Publication No. FHWA-RD-95-119, U.S. DOT, Federal Highway Administration, Washington, DC, 1995.

Koppa, R. J., P.E., "Motor Vehicle Adaptive Equipment and Modifications," Transportation in an Aging Society: A Decade of Experience, Conference Proceedings, Transportation Research Board, Washington, DC, in Preparation. 
LePore, P.R., "When You Are Concerned - A handbook for families, friends and caregivers worried about the safety of an aging driver," Older Driver Family Assistance Project, New York State Office for the Aging, Albany, NY 2000.

Lerner, N., Williams, A. and Sedney, C., "Risk Perception in Highway Driving," Final Report, FHWA Project No. DTFH61-85-C-00143, 1988.

Malfetti, J. L. and Winter, D. J. "Safe and Unsafe Performance of Older Drivers: A Descriptive Study." AAA Foundation for Traffic Safety: Falls Church, VA, 1987.

McKnight, A. J., and Stewart, M. A. "Development of a Competency Based Driver License Testing System." California Department of Motor Vehicles, Contract No. 88-424, 1990.

McKnight, A. J., and Urquijo, J. I. "Signs of Deficiency Among Elderly Drivers." Transportation Research Record, 1405: Washington, DC, 1993.

Miller, G. A. "The magic number seven, plus or minus two: Some limits on our capacity for processing information." Psychological Review, 63, pp. 81-97, 1956.

Milton, K., "Public Information and Education and Its Impact on the Safe Transportation of Older People," Transportation in an Aging Society: A Decade of Experience, Conference Proceedings, Transportation Research Board, Washington, DC, In Preparation.

National Highway Traffic Safety Administration, Conference on Research and Development Needed to improve Safety and Mobility of Older Drivers, National Library of Medicine, Bethesda, MD, August 23-24, 1989.

Staplin, L., and Hunt, L. "Driver Programs," Transportation in an Aging Society: A Decade of Experience, Conference Proceedings, Transportation Research Board, Washington, DC, In Preparation.

Owsley, C. "Traveler Capabilities," Transportation in an Aging Society: A Decade of Experience, Conference Proceedings, Transportation Research Board, Washington, DC, In Preparation.

Pike, J. A., "Protecting the Older Driver-Vehicle Concepts," Transportation in an Aging Society: A Decade of Experience, Conference Proceedings, Transportation Research Board, Washington, DC, In Preparation.

Ray, W. A., Thapa P. B., Shorr, R. I. Medications and the older driver. Clinics in Geriatric Medicine, 9:413-38, 1993.

Rosenbloom, S., "The Mobility of the Elderly: There's Good News and Bad News," Transportation in an Aging Society: A Decade of Experience, Conference Proceedings, Transportation Research Board, Washington, DC, In Preparation.

Schieber, F., "Highway Design Research to Improve the Safety and Mobility of Older Road Users," Heimstra Human Factors Laboratories, University of South Dakota, Draft Version 1.0, Vermillion, SD, September 1999.

Smiley, A., Ph.D., "Adaptive Strategies of Older Drivers," Transportation in an Aging Society: A Decade of Experience, Conference Proceedings, Transportation Research Board, Washington, DC, In Preparation.

Smiley, A., Lee-Gosselin, M., Chipman, M., and MacGregor, C. A study of the amount and type of driving done by Ontario drivers. Report prepared for the Ontario Ministry of Transportation, April, 1991. ISBN 0-7729-8536-7. 
Smiley, A., MacGregor, C., Chipman, M., Taylor, G. and Kawaja, K. Exposure to the risk of crashes: Phase II. Final report prepared for the Ministry of Transportation in Ontario. October, 1997.

Staplin, L., and Fisk, A., "A Cognitive Engineering Approach to Improving Signalized Left Turn Intersections," Human Factors, 33(5), pp. 559-571, 1991.

Staplin, L., Lococo, K. H., Stewart, J. and Decina, L. E., "Safe Mobility for Older People Notebook," DOT HS 808 853, Contract CTNH22-06-C-05140, Interim Technical Report Oct. 1996 - Apr. 1999, National Highway Traffic Safety Administration, Washington, DC, April 1999.

Staplin, L., Lococo, K. H., McKnight, A. J., McKnight, A. S. and Odenheimer, G. L., "Intersection Negotiation Problems of Older Drivers," DOT HS 808 850, Contract No. CTNH22-93-C-05237. National Highway Traffic Safety Administration, Washington, DC, September 1998.

Staplin, L., "Highway Enhancements to Improve the Safety and Mobility of Older Road Users: Practical Applications," Transportation in an Aging Society: A Decade of Experience, Conference Proceedings, Transportation Research Board, Washington, DC, In Preparation.

Suen, L. "Mobility Alternatives for Seniors," Transportation in an Aging Society: A Decade of Experience, Conference Proceedings, Transportation Research Board, Washington, DC, In Preparation.

Transportation Research Board, "Transportation in an Aging Society - Improving Mobility and Safety for Older Persons," Vol. Technical Papers, Committee for the Study on Improving Mobility and Safety for Older Persons, National Research Council, Washington, DC, 1988.

Transportation Research Board, "Transportation in an Aging Society - Improving Mobility and Safety for Older Persons," Vol. 1 Committee Report and Recommendations, Committee for the Study on Improving Mobility and Safety for Older Persons, National Research Council, Washington, DC, 1988.

U.S. Department of Transportation, "Improving Transportation for a Maturing Society," DOT-P10-07-01, Office of the Assistant Secretary for Transportation Policy, Washington, DC, , January 1997.

Wallace, R. B., Ph.D. and Franc, D., "Literature Review of the Status of Research on the Transportation and Mobility Needs of Older Women," DOT HS 808 949, National Highway Traffic Safety Administration, Washington, DC, April 1999.

Wegner, D. M., Erber, R., \& Raymond, P., "Transactive Memory in Close Relationships," Journal of Personality and Social Psychology, pp. 923-929, 1991. 


\section{Appendix 1}

\section{LITERATURE REVIEW}

The purpose of the literature review was to provide a brief overview of some of the relevant literature that has been useful in identifying possible research and implementation problem statements. A full, comprehensive review of all of the relevant topic areas was not attempted. Those who wish a more detailed review are directed to the proceedings of the November 1999 meeting, when they become available.

Much of the information reported here was drawn from the reviews produced by participants of the November 1999 meeting. Many of these were "working papers" and, as such, they lacked reference lists, tables, and/or figures. Some of these reviews were drafts marked "DO NOT CITE", "DO NOT QUOTE" "FOR DISCUSSION ONLY", etc., and were to be used only for background information. Accordingly, this information is discussed but not cited directly in the discussion that follows' ${ }^{1}$.

In the discussion that follows, the following general topic areas have been briefly addressed:

$\begin{array}{ll}\text { - } & \text { The At-Risk Population } \\ \text { - } & \text { At-Risk Drivers and Crashes } \\ \text { - } & \text { Sensory/Perceptual Problems } \\ \text { - } & \text { Pognitive Challenges } \\ \text { - } & \text { Errors Committed by Older Drivers } \\ \text { - } & \text { Older Pedestrians } \\ \text { - } & \text { Pdaptive Strategies } \\ \text { - } & \text { Desic Information \& Education } \\ \text { - } & \text { Driving Cessation } \\ \text { - } & \text { Screening Instruments } \\ & \text { Mobility Alternatives }\end{array}$

\section{THE AT-RISK POPULATION}

\section{Older Drivers}

Crash rates of older drivers have been exhaustively reviewed and will not be repeated here in detail. Older drivers have low crash rates per capita. When exposure is taken into account, however, older drivers have higher crash rates than any other group except for teenagers. Because of this, older drivers have been the focus of important research efforts.

\section{Defining the "Older" Adult}

It is clear that the definition of "older" varies considerably. In one study, "middle-aged drivers" were ages 25-65, while "older drivers" were those over 65. In another study, the entire "older" sample consisted of drivers between 60 and 65 . A 62-year-old driver, then, might have been classified as "middle aged" by one study and "older" by another. This inconsistency is understandable, given that certain difficulties (e.g., vision problems) can typically begin at fairly young ages, while crash rates do not rise dramatically

'When discussed, an unciteable draft may be referred to as a "recent review". 
until older ages. However, the literature as a whole might be well-served by a more consistent definition of "older."

\section{Characteristics of Older Drivers and Older Pedestrians}

The population of Americans over 65 will grow dramatically in the coming years, both in absolute numbers and in proportion to the rest of the population. A majority of them will be female, given that men tend to die younger than women (see Wallace \& Franc, 1999). Concurrently, the proportion of these seniors who are non-white will also increase. A recent review emphasizes the need to recognize racial and ethnic differences in travel patterns. White seniors tend to make more trips than seniors of color, and are less likely to use public transportation. Many older drivers have made no plans for alternatives to driving. Many of those who have thought about alternatives expect to rely on friends and family for transportation. Elders who live alone, have no close family, and have less money will be at a disadvantage when they stop driving.

The current characteristics of older adults may not adequately predict the behavior of older adults in 20 years. Cohort effects may strongly impact the expectations and behavior of the currently-aging population. That is, the baby boom generation may not behave the same way at age 70 that current $70-$ year-olds behave. Baby boomers may not accept authority as easily as the current older generation (e.g., may not accept a doctor's advice to stop driving) and, as suggested by Sterns, Sterns, Aizenberg, and Anapolle (1997), baby boomers may be more likely to engage in high-risk behavior.

On the other hand, baby boom women are more likely than their older counterparts to have driven since youth; may be more experienced with high-density traffic, fast speeds, and complicated traffic patterns; and may have more experience overall (see Hakamies-Blomqvist, in preparation).

\section{"Older" and "At-Risk" Are Not Synonyms}

In recent years, researchers have refocused their efforts from "older drivers" to those at risk. It is important to remember that although the prevalence of driving difficulties increases with age, "at-risk" and "older" are not synonymous. Visual, cognitive, and physical problems can occur at any age and complicate the driving task. Similarly, old age alone does not necessarily indicate the presence of any of the characteristic "older driver" problems (Transportation Research Board, 1988).

\section{AT-RISK DRIVERS AND CRASHES}

When evaluating at-fault crashes, fault is generally assigned by the law enforcement officer who responds to the crash. The responding officer must often sort through conflicting statements and determine the cause of the crash. Because of the strong cultural bias against older drivers, it is possible that fault may sometimes be inaccurately assigned to an older driver involved in a crash. Thus, caution must be used when examining at-fault crash data.

That said, older drivers are involved disproportionately in right-angle crashes and in those involving a complicated maneuver. Specifically, older drivers are more likely to experience crashes at intersections (particularly while turning left across traffic) and while merging, exiting, or changing lanes on a limitedaccess highway. Older drivers are more likely to be cited for failure to yield right-of-way (Staplin \& Lyles, 1991).

Older drivers are also often reported to be disproportionately represented in fatal crashes, and that proportion has increased since 1986 (Hakamies-Blomqvist, in preparation). Although that finding is often interpreted to mean that older drivers are worse drivers, Hakamies-Blomqvist (in preparation) reviews Maycock's 1997 assertion that much of the overrepresentation is due to the "frailty bias". That is, crashes involving older drivers are more likely to end up in the "fatality" category simply because older drivers are frail and more likely to be killed in a given crash than a younger person. Although the overrepresentation still exists, the curve flattens out considerably when the frailty bias is taken into account. 


\section{SENSORYIPERCEPTUAL PROBLEMS}

Aging is associated with multiple changes in sensory and perceptual capabilities. A very brief summary of some these changes follows.

\section{Vision}

Aging frequently is associated with a number of changes to vision (see Owsley, in preparation; and Staplin, Lococo, McKnight, McKnight \& Odenheimer, 1998 for reviews). These include thickening of the lens of the eye, which can interfere with close-up acuity and slow the process of refocusing on more distant targets. The lens also tends to yellow with age, which can reduce color perception. The formation of cataracts causes a decline in acuity and greater vulnerability to glare. Changes in the retina cause problems, and macular degeneration can destroy central vision. Glaucoma reduces peripheral vision. Spatial vision declines with age, as do static acuity and dynamic visual acuity. The prevalence of all these problems increases with age.

The relationships between various visual measures and crashes are mixed (see Owsley, in preparation, for a review). For example, the presence of monocularity does not reliably predict performance. And although it seems obvious that acuity is necessary for driving, static acuity in general has not been reliably predictive of crashes. Drivers may compensate well for a loss of acuity, or it may be that a restriction of range is involved: because static acuity is a requirement for licensure, drivers with very poor vision lose their licenses. Culturally, the need for acuity is very well-accepted, so it may also be that drivers self-regulate (restrict or cease) their driving when acuity is compromised - more than they would for other risk factors (e.g., restricted neck motion).

More reliably, glaucoma, cataracts, and declines in contrast sensitivity are related to at-fault crashes. Severe decreases in visual field are also related to at-fault crashes (Owsley, in preparation; Staplin et al., 1998).

Diabetic retinopathy is a difficult issue to address. Although it may be related to crashes, diabetic retinopathy is of course confounded with diabetes itself. Because the disease can have other effects impacting on driving, it is difficult to isolate the effect of diabetic retinopathy. Specifically, the severity of the disease, the individual patient's level of control, the frequency of hypoglycemic reactions and their accompanying cognitive deficits, other complications (e.g., loss of sensitivity in extremities, cardiovascular damage, high blood pressure) and effects of medication can all complicate the study of diabetic retinopathy and crashes.

\section{Depth Perception}

Perception of angular motion declines with age, and appears to be related to a decline in neural mechanisms caused by aging rather than a particular pathology (see Staplin et al., 1998). Compared to younger drivers, older drivers inaccurately estimate approaching vehicle speeds. This effect may be strongly related to the overrepresentation of older drivers in crashes when turning left across traffic, and when changing lanes or merging/exiting on limited access roads. When determining gap acceptance, older drivers tend to use the distance of the approaching vehicle, rather than the speed of the approaching vehicle. This leaves them vulnerable to crashes with vehicles traveling faster than the stream of traffic.

\section{Visual Attention}

The driving task places complex demands on visual and cognitive processing skills. The Useful Field of View (UFOV) test measures selective and divided attention and is therefore a measure of both visual status and visual information processing. The UFOV test measures the visual field area over which one can use rapidly presented information. Reductions in UFOV are associated with at-fault crash involvement (see Owsley, in preparation, for a review) and with simulator performance (Walker, Sedney \& Mast, 1992; as reviewed by Staplin, 1998). 
The UFOV test is expensive and requires administration by a health care professional (Ball \& Owsley, 1991). Because of these limitations, the instrument is unlikely to be useful as a licensing screen.

\section{COGNITIVE CHALLENGES}

\section{Memory}

\section{Types of Memory}

Traditionally, memory has been conceptualized as having three aspects: sensory (iconic/echoic) memory, short-term (primary) memory, and long-term (secondary) memory. These have typically dealt with memory as a storage function. As reviewed by Staplin (1998), older adults are more susceptible to iconic interference from distraction, and their iconic memory tends to be briefer than for younger adults. Short-term memory does not show reliable age effects, with the usual capacity of $7 \pm 2$ being a robust finding (e.g., Miller, 1963). Long-term memory, however, is vulnerable to age deficits, particularly in freerecall paradigms (e.g., Craik, 1977).

\section{Working Memory}

More recently, the concept of working memory has become a useful way of understanding immediate processing of information (Anderson, 1993). Working memory is thought of not simply as a storage function, but also as a stage where information is processed. It is helpful to think of working memory as the immediate, short term processing and storage area, where moment-by-moment cognitive operations occur. Therefore, the concept of working memory includes both short-term memory AND immediate processing functions. Working memory is not an infinite resource and has capacity limitations (Just and Carpenter, 1992).

Older adults exhibit slower processing of information than younger adults (see review, Staplin, 1998). As a result, working memory as a whole is not as efficient. Particularly, older adults show deficits in processing spatial information. Because the driving task places great demands on working memory (including spatial processing), working memory deficits are likely to strongly impact the driving task.

Reduced working memory capacity may be amenable to corrective design practices. Advance signing intended to remind drivers of a decisional rule (LEFT TURN MUST YIELD ON GREEN O) resulted in improved maneuver decision responses for older drivers (Staplin and Fisk, 1991).

Modifications designed to lessen demands on working memory (e.g., advance signing for TCDs/mid-block street signing) for older drivers may also benefit young, inexperienced drivers. Inexperienced drivers have not yet automatized the driving task and must devote attentional capacity to basic activities such as lanekeeping. The same modifications intended to compensate for older drivers' reduced working memory may also compensate for inexperienced drivers' overloaded capacities.

\section{Attention}

\section{Attention-Switching}

One capacity important to driving is the ability to quickly reorient attention to relevant stimuli (Kahneman, Ben-Ishai \& Lotan, 1973). For example, drivers must be able to quickly transfer attention to a potential threat. Both visual (Avolio, Alexander, Barrett \& Sterns, 1981) and auditory (Gopher \& Kahneman, 1971) measures of attention-switching have demonstrated an association between this ability and reduced crash risk (Kahneman et al., 1973; Avolio et al., 1981, Mihal \& Barrett, 1976; cf. McKenna, Duncan \& Brown, 1986). 


\section{Divided Attention}

Drivers also need to be able to attend to multiple stimuli when driving. For example, drivers must concurrently control the vehicle, monitor other vehicles and pedestrians, read signs, and navigate toward their destination. The ability to divide attention among competing stimuli is a critical process. Older drivers show a decreased ability to divide attention (see review, Staplin, 1998). It appears that this may be at least partly due to a reduced efficiency in the visual search process, which is especially affected by age.

\section{Dementia}

Dementia occurs when there is a progressive loss of cognitive function. It is characterized by impairments in memory, abstract thinking, judgment, and/or personality change. The different types of dementia are covered well elsewhere and will not be reviewed here.

Dementia increases with age, as do the overall prevalence of conditions associated with reduced cognitive function (e.g., Alzheimer's Disease, strokes, Parkinson's Disease, diabetes, cardiovascular damage, and side effects of medication). Demented drivers have higher crash rates, particularly when the dementia is severe. Complicating the picture, dementia sufferers are notoriously poor at selfevaluation and often do not realize the extent of their impairment. However, a diagnosis of dementia alone does not appear to be a good basis for license revocation. Instead, severity might be a more reasonable basis for restricting or revoking licensure.

\section{PHYSICAL AND PSYCHOMOTOR ABILITIES}

\section{Reaction Times}

Findings regarding older drivers' perception-reaction times are mixed. In general, older adults' responses are believed to be slower. Yet in certain well-learned tasks, older adults show no deficits.

This conflict may be resolved in two ways: first, by the often-reported finding that older adults show excellent crystallized knowledge and abilities, but have deficits in fluid knowledge and abilities (e.g., Lezak, 1981). That is, older adults tend to recall established facts and procedures very well, but may have difficulty manipulating information and responding in unfamiliar ways. This is true on very low level as well as higher-level tasks: older adults often show no deficits in simple button-press reaction time studies, but are slower in decision reaction time tasks. On a higher level, older adults perform well on rote tasks but have difficulty generating new responses.

Congruent with this, Knoblauch, Nitzburg and Seifert (1995) found that older drivers had problems with areas such as toll plazas where the correct course of action was unclear: the lack of guides such as lane lines and the unpredictability of other vehicles caused particular difficulties for older drivers. In addition, older drivers listed unfamiliar locations and unexpected traffic patterns as causing problems. It appears that fluid driving responses are especially difficult for older drivers.

The second solution to the puzzle lies in the cumulative effect of small differences in response times. The combination of slowed cognitive processing and slowed motor responses causes a decrement in speed of psychomotor responses. For example, the series of events required to detect a hazard, decide on a response, initiate and execute the response (or series of responses) are quite complex. A very small delay in each of the steps results in a significant slowing overall (e.g., Staplin, Lococo \& Sim, 1990; as reviewed by Staplin et al., 1998).

In addition, older drivers take longer to react when they have time to do so, even in a simple task. Knoblauch, Nitzburg, Reinfurt, Council, Zegeer and Popkin (1995) found that some older drivers, when far from the onset of an amber signal, took longer to decelerate than younger drivers. When close to the signal at the onset of the amber phase, older drivers responded no differently than younger ones. It 
appears that older drivers' slower responses were not necessarily inappropriate, and not necessarily uncontrollable.

\section{Motor Responses}

In older adults, movements are made more slowly and are less coordinated (see Staplin, 1998, for a review). Head and neck mobility may be compromised, particularly when arthritis is present. This may negatively affect drivers' ability to check blind spots, look to the rear of the car, and quickly turn their heads to redirect visual attention. Some movement problems, however, are improved by exercise and so may be correctable, at least to some degree.

\section{Physical Risk Factors}

As reviewed by Marottoli (1996), several physical conditions may raise crash risk. These include cardiovascular disease, sleep apnea, chronic pulmonary disease, cerebrovascular conditions (e.g., strokes), diabetes (particularly during hypoglycemic reactions), arthritis, and side effects of medications. These conditions are likely to cause difficulties with the driving task.

Diller, Cook, Leonard, Reading, Dean and Vernon (1999) reviewed the crash records in Utah of restricted and unrestricted drivers with medical conditions. They found that drivers with medical conditions (both restricted and unrestricted) had higher crash and at-fault crash rates than comparison groups. It seems clear that many medical conditions are associated with increased crash and at-fault crash rates.

\section{ERRORS COMMITTED BY OLDER DRIVERS}

Unsafe driving practices have been extensively documented (see McKnight \& Stewart, 1990; McKnight \& Urquijo, 1993; and Malfetti \& Winter, 1987). In general, mistakes made by older drivers tend to include inadequate search \& scan, difficulties in lane keeping, incorrect vehicle positioning for turns (including both lane selection and lane-keeping), inappropriate or delayed stopping, unsignaled lane changes, and failing to respond appropriately to road signs or signals.

\section{OLDER PEDESTRIANS}

Although there is far less research on older pedestrians, it is crucial to remember that the findings of reduced visual, cognitive and physical abilities have implications for older pedestrians as well as drivers. Although pedestrians do not pilot vehicles, they are required to deal with the same demanding environment that drivers must navigate. For example, when crossing a street, pedestrians must determine gap acceptability, predict vehicle trajectories, make decisions and execute an ambulatory maneuver. At a busy intersection, they have as challenging a task as a driver who wishes to execute a left turn across traffic, but do not have the visibility or the physical protection of a vehicle. Kerschner \& Aizenberg (1999) found that older pedestrians indicate that they are concerned about safety, inadequate timing of traffic signals, poor road conditions, and cars turning right on red.

In addition, older pedestrians may constitute a more impaired population than older drivers. When an older driver accumulates evidence of impairment and decides to cease driving, he or she may often become a pedestrian, particularly in urban areas. As a result, older pedestrians may include those who no longer have the visual, cognitive and/or motor responses necessary for driving.

Very little is known about older pedestrian crash risk and exposure in the U. S. In Victoria, Australia, Fildes (1997) found that, if adjusted solely for difference in population numbers, older people were overrepresented in fatality and injury pedestrian crashes. This, however, does not adjust for time or distance spent walking. Almost nothing is known regarding fault of older pedestrian crashes. Knoblauch et al. (1995) reported that about a third of deaths of pedestrians over age 65 occurred at intersections. 


\section{ADAPTIVE STRATEGIES}

Older drivers often adapt quite well to their changing capabilities. Older drivers show less optimistic and self-serving biases than younger drivers and often are aware that they are less versatile in unexpected situations: they acknowledge an increased likelihood of an accident compared to younger drivers (Holland, 1993). Older drivers generally perceive risk or hazard to be higher than younger drivers do (Lerner, Williams \& Sedney, 1988; Raymond, Seifert, Nitzburg, McKnight, Tippetts, \& Knoblauch, 1999). On a more detailed level, older drivers correctly perceive that crash risk is higher at intersections (Lerner et al., 1988) and that crash risk or hazard are higher when merging or exiting on a limited-access roadway (Lerner et al., 1988; Raymond et al., 1999).

In a recent review, Smiley (in preparation) utilizes Michon's (1985) framework of three levels of behavior: strategic (high-level decisions ), tactical (moment-to moment decisions such as speed choice), and operational (second-to-second behavior, which is often highly automatized). Smiley categorized older drivers' adaptations within this framework and showed that older drivers are most able to affect their strategic and tactical decisions, but have difficulty in changing their operational behavior. That is, older drivers can choose to live close to their destinations (a strategic behavior that is fairly rare); they can and do make strategic changes such as reducing both their overall exposure and their higher-risk exposure (such as bad-weather and night driving), and they are less likely to drink and drive. On the tactical level, older drivers choose lower speeds, allow longer headway, and wait for larger (longer distance) gaps. Operational behaviors, however, are difficult to affect due to their automaticity.

In general, older drivers tend to reduce their exposure by driving less and by avoiding driving in poor conditions (e.g., night, bad weather, rush hour, etc.) (Hakamies-Blomqvist, in preparation; Knoblauch et al., 1995). They drive more slowly, have more conservative gap acceptance, and are less likely to smoke or adjust the radio while driving (Hakamies-Blomqvist, in preparation).

Some adaptations are social in nature. Raymond et al. (1999) noted from focus groups that older couples sometimes direct and assist each other in driving. As one couple stated, "It takes both of us to drive." Previous research has indicated that spouses use each other as external memory sources (see Wegner, Erber and Raymond, 1991). For driving, it is possible that older couples may use each other as external processing capacity as well. The passenger may often navigate, read signs, assist in hazard detection, and remind the driver of tasks. This adaptation may counteract some of the limitations posed by reduced working memory capacity.

\section{PUBLIC INFORMATION \& EDUCATION}

\section{Objectives}

A social marketing campaign, according to Milton (in preparation), will attempt to accomplish the following: to help older people use techniques and behaviors that will allow them safe driving for as long as possible; to help with driving cessation; and to educate the public with accurate information about older drivers (rather than the occasional sensationalized incident).

\section{Campaign Guidelines}

Successful public education campaigns take the following into account, according to Kanouse (1988): information must specifically address the audience's needs; it should give information the audience does not already have; it should take advantage of existing motivation (give them information that helps them do what they already wanted to do); it should empower the audience rather than making them feel helpless; it should contain information that is relevant to decisions; information should be provided in a way that takes into account the method and time of use (e.g., radio is an effective medium because it reaches people while they drive); it should help people reframe their thinking; and it should be presented repeatedly. A well-designed transportation PI\&E effort will take these recommendations into account. 


\section{Reaching Professionals}

As reviewed by Milton (in preparation), a Lifespan survey showed that professionals such as doctors, nurses, therapists, psychologists, and others seek information from motor vehicle departments, professional journals, professional societies, continuing education and conferences. They infrequently used media, experience, research, or state health departments. Efforts designed to reach these professionals should take this information into account.

\section{Reaching Drivers and Their Families}

State motor vehicle departments and health and social service agencies may be the fastest means of reaching older drivers and their families in an educational campaign, but efforts are most influential when they include local channels such as churches, senior centers, libraries, post offices, etc. (Milton, in preparation).

Recently, the state of New York has issued a publication aimed at families of older drivers (LePore, 2000). This handbook is a comprehensive guide for families dealing with driving cessation and covers a wide variety of topics, including the following: behaviors that indicate the driver is at risk; broaching the subject of driving cessation; interventions; reporting hazardous drivers; relevant agencies; adjustment to driving cessation; transportation alternatives; suggestions for extending the ability to drive safely; and advance planning for driving cessation.

AAA has also issued a handbook for friends and families of older drivers (AAA, 2000). Among other topics, it gives an overview of age-related changes; provides a brief assessment, suggests strategies to prolong safe driving, lists transportation alternatives, suggests interventions and provides information about reporting unsafe drivers.

\section{DESIGN COUNTERMEASURES}

As summarized by Staplin (in preparation), potential countermeasures can assist older drivers. Older drivers would be helped by a long list of recommendations. In general, these include redundant signing, increased contrast of markings, increased use of delineation and pavement markings, allowing greater margins for error (e.g., wider turn lanes, shoulders, lengthened perception-reaction time used by designers), lengthened WALKK phase of pedestrian signals, and simplification/shortening of messages used in variable message signs. For a review of research supporting highway design modifications for older drivers, see the Proceedings of Transportation in an Aging Society: A Decade of Transportation Research Board (in preparation). For a full list of recommendations, please see the Federal Highway Administration's Older Driver Highway Design Handbook. For example, increased contrast in signs and pavement markings can help older drivers at night. Adding delineation wherever possible (e.g., marking curbs themselves as well as having the edgeline on the road surface) would also help. For intersections, a number of modifications would improve older driver performance; for example, constructing roadways so that they meet at a 90-degree angle, allowing wide turn lanes and shoulders, lengthening the perception-reaction time used by designers, would assist older drivers.

\section{DRIVING CESSATION}

Self-regulation is an important aspect of driving for the older population. Many older adults continue to drive until very old, but very frequently reduce their risk by reducing their exposure and particularly their high-risk exposure (Hakamies-Blomqvist, 1994).

Many elders elect to stop driving because of failing eyesight, other medical problems, and the realization that they were driving unsafely (Kerschner \& Aizenberg, 1999). However, many may not be aware of a decline in their abilities. Dobbs (1996) followed a sample of drivers who had failed a DMV assessment and were recommended to stop driving. Three quarters of the drivers said they had been unaware of their need to stop driving. The majority complied immediately. Twenty percent, however, disregarded the recommendation and continued to drive. 
Self-regulation cannot be solely relied upon. Many older adults dread the thought of losing their ability to drive and refuse to consider alternatives, according to recent reviews. When self-regulation fails, outside regulation must be considered.

\section{SCREENING INSTRUMENTS}

The Gross Impairments Screening (GRIMPS) attempts to detect impairments in critical functional abilities (rather than focusing on a particular medical diagnosis) (Staplin \& Hunt, in preparation). It measures high and low contrast static visual acuity, intact scanning pattern, visualization/understanding of spatial relationships, visual search and sequencing, information processing speed, divided attention, attention switching, lower limb mobility, upper limb mobility, and head/neck flexibility. The GRIMPS test is currently under pilot testing in the state of Maryland.

A list of NHTSA-sponsored driver assessment programs nationwide can be found in Staplin \& Hunt (in preparation), as can a list of state-by-state requirements for license renewal.

\section{MOBILITY ALTERNATIVES}

Non-driving modes of transportation can apply to any part of the population who does not drive. As summarized in "Mobility Alternatives for Seniors", non-driving options include public transportation such as fixed route rail, bus, paratransit, community transportation (e.g., community bus), demand-responsive transit (e.g., dial-a-ride), flex-route, Independent Transportation Networks, volunteer services, taxis, bicycles or tricycles, hitchhiking, and walking.

Different capabilities are needed in order to utilize services; for example, a bus passenger must be able to get to the bus stop and board the bus. Therefore, the abilities of the individual determine what options he or she is able to use. In addition, potential users must have information about options available to them, and must be able to pay for services if needed. Further, several of the options can be difficult to use because of scheduling, eligibility restrictions, and limited capacity.

The geographical location of users determines their options as well. Urban dwellers have different options from rural dwellers (e.g., more access to traditional buses and trains). Despite having more options, city dwelling elders use public transportation relatively lightly (Suen, in preparation). This may be because of accessibility issues. It may also be because older adults feel more vulnerable to threats such as crime and bad weather - a young person may be cautious when waiting for a bus in the dark, but an elderly person may simply elect not to make the trip.

A framework of transportation options, information needs, costs, service providers, and necessary abilities of users is given in Suen (in preparation). As Kerschner \& Aizenberg (1999) point out, older adults tend to look for transportation that fulfills the "Five A's": Availability, Accessibility, Affordability, Acceptability and Adaptability.

Most frequently, elders plan to obtain rides from someone with a private car, usually a friend, neighbor or daughter (Kerschner \& Aizenberg, 1999). According to Freund (1996), the vast majority of these rely on a daughter. Unfortunately, the population of those who need care (and rides) is increasing faster than those who are available or willing to provide care (Wilson, 1994). The potentially-caregiving younger generation is frequently occupied with childrearing and can become quickly overextended. Caregivers are most likely to be daughters, but cultural changes are making many of those individuals unavailable for the task: adult children are increasingly likely to live far away, daughters are increasingly likely to hold fulltime jobs and be unavailable during the day, and ever-decreasing family sizes reduce the pool of adult offspring able to give rides or other caregiving. Older adults are less and less able to rely on their children for day-to-day transportation.

As a recent review notes, housing patterns, land use and travel needs are geared toward car-based mobility. Without dramatic change, vulnerable, non-driving adults will be left with little access to social contact, necessary goods and services, and the outside world. 


\section{Appendix 2}

Research Projects Suggested and Prioritized at the November, 1999 Meeting Included in Literature Review of Current Project

\begin{tabular}{|c|c|c|}
\hline Title & $\begin{array}{l}\text { General Approach/ } \\
\text { Type of Study }\end{array}$ & $\begin{array}{c}\text { Desired Outcomes } \\
\text { (Question to be Answered) }\end{array}$ \\
\hline Lost Mobility: The Cost & Cost analysis & $\begin{array}{l}\text { Quantify cost of loss of mobility } \\
\text { on health care costs to society }\end{array}$ \\
\hline $\begin{array}{l}\text { Do Assessment and Retraining } \\
\text { Programs Improve Driving? }\end{array}$ & Evaluation & $\begin{array}{l}\text { Conduct follow-up of studies of } \\
\text { outcomes of assessment and } \\
\text { retraining programs, including } \\
\text { qualification of remediation } \\
\text { effectiveness }\end{array}$ \\
\hline $\begin{array}{l}\text { Services For Those Who Stop } \\
\text { Driving }\end{array}$ & PI\&E & $\begin{array}{l}\text { Social marketing to older people } \\
\text { so they know that they are } \\
\text { eligible for services (and to } \\
\text { design services that match their } \\
\text { needs) }\end{array}$ \\
\hline $\begin{array}{l}\text { Evaluation of Transportation } \\
\text { Solutions }\end{array}$ & Evaluate existing programs & $\begin{array}{l}\text { Identify and evaluate successful } \\
\text { transportation solutions } \\
\text { developed in/by } \\
\text { communities/local groups } \\
\text { (mobility options) }\end{array}$ \\
\hline $\begin{array}{l}\text { Mobility for Older Adults: The } \\
\text { Benefits }\end{array}$ & Cost analysis & $\begin{array}{l}\text { Quantify social benefits and } \\
\text { disbenefits of remaining mobile } \\
\text { and connected to services } \\
\text { (policy) }\end{array}$ \\
\hline Screening Battery Development & $\begin{array}{l}\text { Development, Evaluation, } \\
\text { Implementation }\end{array}$ & $\begin{array}{l}\text { Develop and evaluate, then } \\
\text { implement, screening tests for } \\
\text { visual, cognitive and/or physical } \\
\text { problems related to crashes } \\
\text { (and test training materials for } \\
\text { administrators) }\end{array}$ \\
\hline Self-regulation & Focus groups, surveys & $\begin{array}{l}\text { How does older driver } \\
\text { behavioral self-regulation } \\
\text { adaptation develop? }\end{array}$ \\
\hline $\begin{array}{l}\text { Screening for Higher-Order } \\
\text { Cognitive Functions }\end{array}$ & Evaluation & $\begin{array}{l}\text { Develop predictive models } \\
\text { through the identification of } \\
\text { assessment tools that take into } \\
\text { account the role of higher order } \\
\text { functions (e.g., judgment) and } \\
\text { level of expertise }\end{array}$ \\
\hline
\end{tabular}




\begin{tabular}{|c|c|c|}
\hline \multicolumn{3}{|c|}{ Appendix 2 (Continued) } \\
\hline Title & $\begin{array}{c}\text { General Approach/ } \\
\text { Type of Study }\end{array}$ & $\begin{array}{c}\text { Desired Outcomes } \\
\text { (Question to be Answered) }\end{array}$ \\
\hline Evaluation of Routine Screening & Evaluation & $\begin{array}{l}\text { Determine benefits/disbenefits of } \\
\text { routine screening of older drivers } \\
\text { (use randomized controlled } \\
\text { trials) }\end{array}$ \\
\hline $\begin{array}{l}\text { The Need for an "Older Adult" } \\
\text { Crash Test Dummy }\end{array}$ & Development & $\begin{array}{l}\text { Crash dummies } \\
\text { - criteria for older persons } \\
\text { - need separate dummy? } \\
\text { - user to examine interior } \\
\text { components }\end{array}$ \\
\hline A Guide for Planners & Policy & $\begin{array}{l}\text { How to get transit-oriented } \\
\text { development/mixed use zoning } \\
\text { adopted }\end{array}$ \\
\hline The Cost of Non-mobility & Cost analysis & $\begin{array}{l}\text { What are economics of non- } \\
\text { mobility to the individual, family } \\
\text { and community? }\end{array}$ \\
\hline $\begin{array}{l}\text { Cost/Benefit of Highway } \\
\text { Modifications }\end{array}$ & Cost/benefit analysis & $\begin{array}{l}\text { Benefits/costs of treatments } \\
\text { (highway) }\end{array}$ \\
\hline $\begin{array}{l}\text { Information on Mobility } \\
\text { Alternatives }\end{array}$ & PI\&E & $\begin{array}{l}\text { Strategies to communicate } \\
\text { mobility alternatives }\end{array}$ \\
\hline $\begin{array}{l}\text { Cooperation Between Interested } \\
\text { Parties }\end{array}$ & Liaison & $\begin{array}{l}\text { Develop more efficient linkages } \\
\text { across agencies, professions, } \\
\text { and others involved in older } \\
\text { driver programs }\end{array}$ \\
\hline Educational Efforts & PI\&E & $\begin{array}{l}\text { Development of overall public } \\
\text { information strategy or social } \\
\text { marketing plan }\end{array}$ \\
\hline Assessment Accessibility & $\begin{array}{l}\text { Survey, focus groups, expert } \\
\text { panel }\end{array}$ & $\begin{array}{l}\text { Identify barriers to seeking driver } \\
\text { assessment-both self referrals } \\
\text { and other referrals (e.g., } \\
\text { physician) }\end{array}$ \\
\hline $\begin{array}{l}\text { Licensure Rates By } \\
\text { Gender/Ethnicity }\end{array}$ & Demographic study - archival & $\begin{array}{l}\text { Examine ethnic/gender } \\
\text { differences in licensing rates for } \\
\text { older persons }\end{array}$ \\
\hline Summary of Knowledge & Literature Review & "Best practices"/lessons learned \\
\hline $\begin{array}{l}\text { Necessary and Discretionary } \\
\text { Trips }\end{array}$ & Focus groups, survey & $\begin{array}{l}\text { Better understanding of how } \\
\text { older people define necessary } \\
\text { and discretionary trips }\end{array}$ \\
\hline
\end{tabular}




\begin{tabular}{|c|c|c|}
\hline \multicolumn{3}{|c|}{$\begin{array}{l}\text { Appendix } 2 \text { (Continued) } \\
\text { jested and Prioritized at the November, } 1999 \text { Meeting } \\
\text { in Literature Review of Current Project }\end{array}$} \\
\hline Title & $\begin{array}{c}\text { General Approach/ } \\
\text { Type of Study }\end{array}$ & $\begin{array}{c}\text { Desired Outcomes } \\
\text { (Question to be Answered) }\end{array}$ \\
\hline Developing Mobility Alternatives & Expert panel, focus groups & $\begin{array}{l}\text { Develop mobility alternatives for } \\
\text { former and high-risk drivers }\end{array}$ \\
\hline $\begin{array}{l}\text { Policy Impact on Access \& } \\
\text { Mobility Patterns of Older } \\
\text { Travelers }\end{array}$ & Evaluation & $\begin{array}{l}\text { Evaluate impact of government } \\
\text { policies (e.g., land use) on } \\
\text { access and mobility patterns of } \\
\text { older travelers (all modes) }\end{array}$ \\
\hline $\begin{array}{l}\text { Transportation Needs of the } \\
\text { Elderly: Mobility patterns vs. } \\
\text { Lifestyle Patterns }\end{array}$ & Cost Analysis & $\begin{array}{l}\text { Determine magnitude of impact } \\
\text { of lifestyle changes and mobility } \\
\text { patterns of older persons on } \\
\text { transportation needs }\end{array}$ \\
\hline $\begin{array}{l}\text { Evaluation of Mobility PI\&E } \\
\text { Resources }\end{array}$ & Evaluate PI\&E/Expert Panel & $\begin{array}{l}\text { Community-level evaluation of } \\
\text { senior mobility examine } \\
\text { materials/strategies for: } \\
\text { - appropriateness of messages } \\
\text { and delivery system } \\
\text { - cultural and geographic } \\
\text { appropriateness } \\
\text { - financial realities }\end{array}$ \\
\hline $\begin{array}{l}\text { Evaluation of Potential } \\
\text { Improvements to Public } \\
\text { Transport }\end{array}$ & Expert Panel & $\begin{array}{l}\text { Study changes needed to } \\
\text { improve transportation mobility } \\
\text { rate, re: older population }\end{array}$ \\
\hline $\begin{array}{l}\text { Alternative Transportation } \\
\text { Users: Needs And Capabilities }\end{array}$ & Survey & $\begin{array}{l}\text { What are needs and capabilities } \\
\text { of alternative transportation } \\
\text { users, including pedestrians? }\end{array}$ \\
\hline Identification of New Messages & PI\&E & $\begin{array}{l}\text { Identification of new messages } \\
\text { - identify successful models for } \\
\text { other social issues that can be } \\
\text { adapted and tested for senior } \\
\text { market }\end{array}$ \\
\hline $\begin{array}{l}\text { Assessment of Medication } \\
\text { Effects on Older Drivers }\end{array}$ & Expert Panel & $\begin{array}{l}\text { Medication (prescription and } \\
\text { over the counter): What are the } \\
\text { connections and implications for } \\
\text { the older driver? }\end{array}$ \\
\hline $\begin{array}{l}\text { Impact of Federal Laws on State } \\
\text { and Local Services }\end{array}$ & Archival Study/Expert Panel & $\begin{array}{l}\text { How federal laws and } \\
\text { regulations impact state/local } \\
\text { services (e.g., jurisdictional, } \\
\text { boundaries, etc.) (include effect } \\
\text { on minorities) }\end{array}$ \\
\hline
\end{tabular}




\begin{tabular}{|c|c|c|}
\hline \multicolumn{3}{|c|}{$\begin{array}{l}\text { Appendix } 2 \text { (Continued) } \\
\text { gested and Prioritized at the November, } 1999 \text { Meeting } \\
\text { in Literature Review of Current Project }\end{array}$} \\
\hline Title & $\begin{array}{c}\text { General Approach/ } \\
\text { Type of Study }\end{array}$ & $\begin{array}{c}\text { Desired Outcomes } \\
\text { (Question to be Answered) }\end{array}$ \\
\hline $\begin{array}{l}\text { Trips Not Taken: Cost and } \\
\text { Willingness to Pay }\end{array}$ & Cost Analysis & $\begin{array}{l}\text { Quantify trips not taken and } \\
\text { willingness to pay for those } \\
\text { trips/variety of means }\end{array}$ \\
\hline Dynamic Sign Legibility & Field Test & $\begin{array}{l}\text { Dynamic field Testing of } \\
\text { highway sign legibility }\end{array}$ \\
\hline $\begin{array}{l}\text { Older Adults' Transportation } \\
\text { Needs: Case Studies }\end{array}$ & Case Studies & $\begin{array}{l}\text { Comparative case studies on } \\
\text { how older persons currently } \\
\text { meet (or do not meet) } \\
\text { transportation needs }\end{array}$ \\
\hline $\begin{array}{l}\text { Standardization of Training and } \\
\text { Standards of Driver } \\
\text { Rehab/Assessment } \\
\text { Professionals }\end{array}$ & Expert Panel & $\begin{array}{l}\text { Identify research issues involved } \\
\text { in potential standardization of } \\
\text { training and standards of driver } \\
\text { rehab/assessment professionals }\end{array}$ \\
\hline $\begin{array}{l}\text { Evaluation of Older Driver } \\
\text { Training Programs }\end{array}$ & Evaluation & $\begin{array}{l}\text { Older person driver training } \\
\text { effectiveness }\end{array}$ \\
\hline
\end{tabular}




\section{Appendix 3}

Implementation Projects Suggested and Prioritized at the November, 1999 Meeting Included in Literature Review of Current Project

\begin{tabular}{|c|c|c|}
\hline Title & $\begin{array}{l}\text { General Approach/ } \\
\text { Type of Study }\end{array}$ & $\begin{array}{c}\text { Desired Outcomes } \\
\text { (Question to be Answered) }\end{array}$ \\
\hline $\begin{array}{l}\text { State of the Practice: } \\
\text { Partnerships Between Entities }\end{array}$ & State of the Practice: & $\begin{array}{l}\text { Best practices on public/private } \\
\text { and interagency partnerships } \\
\text { that have been established - } \\
\text { emphasis on solutions to } \\
\text { implementation barriers, } \\
\text { financing, etc. }\end{array}$ \\
\hline At-Risk Driver Assessment Tiers & $\begin{array}{l}\text { Screening/Assessment } \\
\text { Development }\end{array}$ & $\begin{array}{l}\text { Develop multiple tiers of } \\
\text { assessment (e.g., self } \\
\text { assessment tools, education for } \\
\text { medial/law personnel) }\end{array}$ \\
\hline NTPS Survey - Further Analysis & Analysis & $\begin{array}{l}\text { Further detailed analysis of } \\
\text { NTPS survey for older } \\
\text { population sample }\end{array}$ \\
\hline $\begin{array}{l}\text { Alternative Transportation: } \\
\text { What's Working, What's Not }\end{array}$ & Literature Review/Expert Panel & $\begin{array}{l}\text { Best practices report on } \\
\text { establishing/resolving policy } \\
\text { issues and creating funding } \\
\text { mechanisms for alternative } \\
\text { transportation }\end{array}$ \\
\hline Tools for Self-Assessment & Instrument Development & $\begin{array}{l}\text { Self assessment tools for } \\
\text { different users }\end{array}$ \\
\hline $\begin{array}{l}\text { Training Programs: Strategies } \\
\text { and Alternatives }\end{array}$ & Archival/State of Practice & $\begin{array}{l}\text { Document classroom/on-road } \\
\text { skills training programs which } \\
\text { include information on } \\
\text { alternative transportation options } \\
\text { and adaptive strategies }\end{array}$ \\
\hline $\begin{array}{l}\text { Aging and Transportation } \\
\text { Issues: Promoting Awareness }\end{array}$ & PI\&E & $\begin{array}{l}\text { Promote awareness and } \\
\text { education on aging and } \\
\text { transportation issues and } \\
\text { solutions - include } \\
\text { policymakers, consumers, } \\
\text { professionals, service providers, } \\
\text { health and medical, public } \\
\text { community organizations }\end{array}$ \\
\hline $\begin{array}{l}\text { Screening Instruments and } \\
\text { Crash Risk }\end{array}$ & Evaluation/Nalidation & $\begin{array}{l}\text { Pilot test comprehensive } \\
\text { screening and track crash } \\
\text { experience of high risk vs. } \\
\text { others }\end{array}$ \\
\hline Effects of Medication on Driving & PI\&E & $\begin{array}{l}\text { Effective dissemination of } \\
\text { existing knowledge (e.g., } \\
\text { medication effects) }\end{array}$ \\
\hline
\end{tabular}




\begin{tabular}{|c|c|c|}
\hline \multicolumn{3}{|c|}{ Implementation Projects Suggested and Prioritized at the November, 1999 Meeting } \\
\hline Títle & $\begin{array}{c}\text { General Approach/ } \\
\text { Type of Study }\end{array}$ & $\begin{array}{c}\text { Desired Outcomes } \\
\text { (Question to be Answered) }\end{array}$ \\
\hline $\begin{array}{l}\text { The Maryland Model: Further } \\
\text { Testing }\end{array}$ & Pilot Test & $\begin{array}{l}\text { Further pilot test MD at-risk } \\
\text { program (test exportability) }\end{array}$ \\
\hline $\begin{array}{l}\text { Before You Give Up Your Keys: } \\
\text { A Handbook of Options }\end{array}$ & PI\&E & $\begin{array}{l}\text { Pilot test program to make older } \\
\text { drivers and families aware of } \\
\text { options prior to loss of driving } \\
\text { privilege }\end{array}$ \\
\hline Creating Options for Non-Drivers & PI\&E & $\begin{array}{l}\text { Encourage states/communities } \\
\text { to investigate, develop and } \\
\text { promote alternative } \\
\text { transportation solution to } \\
\text { empower individuals to make } \\
\text { informed mobility choices }\end{array}$ \\
\hline $\begin{array}{l}\text { Law Enforcement Program: } \\
\text { Detecting Problem Drivers }\end{array}$ & Curriculum Development & $\begin{array}{l}\text { Develop training programs for } \\
\text { law enforcement to spot problem } \\
\text { drivers - provide referral } \\
\text { avenue - no age discrimination }\end{array}$ \\
\hline $\begin{array}{l}\text { Older Drivers in the } 21^{\text {st }} \text { Century: } \\
\text { Economic Opportunities }\end{array}$ & PI\&E & $\begin{array}{l}\text { Develop forceful statement of } \\
\text { reality of situation to convince } \\
\text { private industry that this is a } \\
\text { positive economic issue }\end{array}$ \\
\hline $\begin{array}{l}\text { Functional Characteristics of the } \\
\text { At-Risk Driver }\end{array}$ & PI\&E & $\begin{array}{l}\text { Develop functional descriptions } \\
\text { of the problems }\end{array}$ \\
\hline $\begin{array}{l}\text { How to Talk with an At-Risk } \\
\text { Driver }\end{array}$ & Curriculum Development & $\begin{array}{l}\text { Provide training to enable } \\
\text { caregivers to communicate } \\
\text { effectively }\end{array}$ \\
\hline Policy Regarding Older Drivers & PI\&E & $\begin{array}{l}\text { Develop and test messages } \\
\text { directed toward policymakers }\end{array}$ \\
\hline
\end{tabular}




\section{Appendix 4}

Unprioritized General Research Concepts Suggested at the November, 1999 Meeting Included in Literature Review of Current Project

\section{General Research Concepts}

Need to look at transportation need for wider community - a universal transportation system-find ways to encourage local agencies to work together (coordination)

Seat belt

- comfort and convenience

- frail and elderly

- warning systems

Early stage dementia driving behavior research

Obstacle detection

- visual

- auditory

- visibility enhancements

Need to understand the symbolic value of auto and why transit is stigmatized (i.e., why people are reluctant to use these services, based on biases)

Controls - standardization, location

Airbags

- side impact

- door panel design

- frail elderly

Displays - HUD's, contrast, maps, character size

Identify and characterize driver evaluators, driver education program

GAP acceptance models (highway)

Define purpose of driver programs

- assessment vs. training

- rehab assessments vs. on-the-road skills

Highway-related ITS devices (highway)

Understand economic incentives when planning for options other than auto

Quantify how service delivery creates the need for driving - include innovative service delivery

techniques (e.g., web)

Operationalize the assessment cascade

Identify the resources available to make driving decisions

Evaluation of rehabilitation system strategies and programs (including promising ones) 


\section{Appendix 5}

Unprioritized General Implementation Concepts Suggested at the November, 1999 Meeting Included in Literature Review of Current Project

\begin{tabular}{|l|}
\hline \multicolumn{1}{|c|}{ General lmplementation Concepts } \\
\hline Educate media so they frame problem correctly \\
\hline Need for training to use "alternative" transportation - lack of familiarity/habit \\
\hline Demonstrate efficacy of highway improvements \\
\hline Use of WWW to provide mobility information and meet some shopping needs \\
\hline Use of 1:40 L.I. \\
\hline Greater dissemination and use of clearview font \\
\hline Awareness - insurance, auto, general public, government and industry leaders, medical \\
\hline Need better connection with private sector \\
\hline Providing additional transportation - not enough - transit/mobility training needed \\
\hline Retrofit old vehicles with new safety features \\
\hline Dissemination of information formal mechanism for "bubbling up" of policy information \\
\hline Catalogue financial resources and identify unique sources \\
\hline Greater use of mixed case highway sign messages \\
\hline
\end{tabular}




\section{Appendix 6}

Additional Research and Implementation Projects Identified During the Review of Research and Materials

\begin{tabular}{|c|c|c|}
\hline Title & $\begin{array}{c}\text { General Approach } \\
\text { Type of Study }\end{array}$ & $\begin{array}{c}\text { Desired Outcomes } \\
\text { (Question to be Answered) }\end{array}$ \\
\hline Older Drivers: Fault or Foul? & Analyze hard-copy crash reports & $\begin{array}{l}\text { Do Older Drivers cause more } \\
\text { crashes, or are they simply less } \\
\text { able to adequately respond to } \\
\text { traffic? (Are they at fault or just } \\
\text { less able to avoid potential } \\
\text { crashes caused by others?) }\end{array}$ \\
\hline $\begin{array}{l}\text { Crashes Involving Older } \\
\text { Pedestrians }\end{array}$ & Exposure study & $\begin{array}{l}\text { Are Older Pedestrians } \\
\text { overrepresented in pedestrian } \\
\text { crashes in the U.S.? }\end{array}$ \\
\hline $\begin{array}{l}\text { Guidelines for Physicians: } \\
\text { Talking to the Older Driver }\end{array}$ & PI\&E & $\begin{array}{l}\text { Physicians often are expected } \\
\text { (by patients and family) to } \\
\text { discuss a patient's ability to } \\
\text { drive. Develop guidelines for } \\
\text { physicians. }\end{array}$ \\
\hline Is a Car Worth the Expense? & PI\&E & $\begin{array}{l}\text { Campaign showing relative cost } \\
\text { of taxi vs. car when few trips are } \\
\text { made }\end{array}$ \\
\hline $\begin{array}{l}\text { Modifications for Older } \\
\text { Pedestrians }\end{array}$ & $\begin{array}{l}\text { Expert Panel, cost-benefit } \\
\text { analysis }\end{array}$ & $\begin{array}{l}\text { What existing pedestrian safety } \\
\text { measures would most benefit } \\
\text { Older Persons? (e.g., lighting, } \\
\text { etc.) }\end{array}$ \\
\hline $\begin{array}{l}\text { PI\&E Measures Nationwide: } \\
\text { What Has Been Effective? }\end{array}$ & Evaluation & $\begin{array}{l}\text { Evaluate success of existing } \\
\text { materials and pinpoint the most } \\
\text { productive lines to continue }\end{array}$ \\
\hline $\begin{array}{l}\text { Passengers of Older Drivers: } \\
\text { Distraction or Assistant? }\end{array}$ & $\begin{array}{l}\text { Investigate performance of ODs } \\
\text { with passengers, particularly } \\
\text { spouses. Assess performance } \\
\text { in simulator while } \\
\text { unassisted/assisted by spouse. } \\
\text { May compare to middle-age } \\
\text { drivers and/or inexperienced } \\
\text { drivers. }\end{array}$ & $\begin{array}{l}\text { Do older couples use each other } \\
\text { as external working memory } \\
\text { sources when driving? Unlike } \\
\text { teens with passengers, ODs with } \\
\text { spouse-passengers may have } \\
\text { lower crash rate. }\end{array}$ \\
\hline Inter-agency Cooperation & & $\begin{array}{l}\text { Cooperate with NIDR to optimize } \\
\text { transportation for those who do } \\
\text { not drive }\end{array}$ \\
\hline Defining "Older" for Researchers & $\begin{array}{l}\text { Review of literature to determine } \\
\text { a reasonable, consistent } \\
\text { definition of "older". } \\
\text { Expert Panel? }\end{array}$ & At what age is a driver "older"? \\
\hline
\end{tabular}




\begin{tabular}{|c|c|c|}
\hline \multicolumn{3}{|c|}{$\begin{array}{l}\text { Appendix } 6 \text { (Continued) } \\
\text { and Implementation Projects Identified During the } \\
\text { eview of Research and Materials }\end{array}$} \\
\hline Title & $\begin{array}{c}\text { General Approach/ } \\
\text { Type of Study }\end{array}$ & $\begin{array}{c}\text { Desired Outcomes } \\
\text { (Question to be Answered) }\end{array}$ \\
\hline $\begin{array}{l}\text { Screening for Performance- } \\
\text { Related Visual Problems }\end{array}$ & Evaluation & $\begin{array}{l}\text { How can vision screening be } \\
\text { improved? What current vision } \\
\text { screening test is most predictive } \\
\text { of crashes? }\end{array}$ \\
\hline Screening for Cognitive Skills & $\begin{array}{l}\text { Literature review, Expert Panel, } \\
\text { basic research }\end{array}$ & $\begin{array}{l}\text { How can cognitive abilities be } \\
\text { assessed? What current } \\
\text { screening test is most predictive } \\
\text { of crashes? }\end{array}$ \\
\hline $\begin{array}{l}\text { Targeting At-Risk Populations } \\
\text { for Screening }\end{array}$ & Expert Panel, literature review & $\begin{array}{l}\text { On what basis should drivers be } \\
\text { required to complete screening } \\
\text { tests? Age? Medical referral? } \\
\text { Insurance company referral? } \\
\text { Crash status? Other criteria? }\end{array}$ \\
\hline $\begin{array}{l}\text { Insurance Companies as } \\
\text { Gatekeepers: Referring At-Risk } \\
\text { Drivers for Screening }\end{array}$ & Liaison & $\begin{array}{l}\text { Explore cooperation with } \\
\text { insurance companies - they can } \\
\text { be gatekeepers. }\end{array}$ \\
\hline $\begin{array}{l}\text { Vehicle Adaptations for Older } \\
\text { Drivers }\end{array}$ & Product development & $\begin{array}{l}\text { Can vehicles be changed to } \\
\text { accommodate the common } \\
\text { physical impairments in older } \\
\text { drivers? }\end{array}$ \\
\hline Referring At-Risk Older Drivers & Expert Panel & $\begin{array}{l}\text { Develop referral system for at- } \\
\text { risk drivers }\end{array}$ \\
\hline $\begin{array}{l}\text { Medication Side Effects and the } \\
\text { Driving Task }\end{array}$ & $\begin{array}{l}\text { Literature Review, expert panel } \\
\text { of physicians }\end{array}$ & $\begin{array}{l}\text { What medications negatively } \\
\text { affect driving ability, and are } \\
\text { there alternatives? }\end{array}$ \\
\hline Promoting Self-Regulation & PI\&E & $\begin{array}{l}\text { How can older drivers be } \\
\text { encouraged to appropriately } \\
\text { self-regulate? }\end{array}$ \\
\hline $\begin{array}{l}\text { Use of Public Transportation: } \\
\text { Barriers and Solutions }\end{array}$ & Focus groups, surveys & $\begin{array}{l}\text { Use of buses/subways by elders } \\
\text { is relatively rare, even when they } \\
\text { are available. Document } \\
\text { reasons. }\end{array}$ \\
\hline $\begin{array}{l}\text { A Cost/Benefit Analysis of } \\
\text { Promising Highway } \\
\text { Enhancements }\end{array}$ & Cost/benefit analysis & $\begin{array}{l}\text { Which modifications are most } \\
\text { beneficial per dollar spent? }\end{array}$ \\
\hline
\end{tabular}




\begin{tabular}{|c|c|c|}
\hline \multicolumn{3}{|c|}{$\begin{array}{l}\text { Appendix } 6 \text { (Continued) } \\
\text { and Implementation Projects Identified During the } \\
\text { view of Research and Materials }\end{array}$} \\
\hline Title & $\begin{array}{c}\text { General Approach } \\
\text { Type of Study }\end{array}$ & $\begin{array}{c}\text { Desired Outcomes } \\
\text { (Question to be Answered) }\end{array}$ \\
\hline $\begin{array}{l}\text { Rural Older Drivers, Crashes, } \\
\text { and Exposure? }\end{array}$ & Survey, crash analysis & $\begin{array}{l}\text { Do rural ODs continue to drive } \\
\text { for longer because of lack of } \\
\text { alternatives? If so, is this related } \\
\text { to crashes? }\end{array}$ \\
\hline $\begin{array}{l}\text { Transportation Needs of Older } \\
\text { Adults in Rural and Suburban } \\
\text { Areas }\end{array}$ & Cost analysis & $\begin{array}{l}\text { Generate a handbook for } \\
\text { transportation planners }\end{array}$ \\
\hline $\begin{array}{l}\text { Pedestrian Safety: Implementing } \\
\text { Current Knowledge at } \\
\text { Intersections }\end{array}$ & Expert panel & $\begin{array}{l}\text { Improve and implement current } \\
\text { knowledge re: walking speed } \\
\text { and comprehension of } \\
\text { Walk/Don't Walk signals }\end{array}$ \\
\hline Edge Lines and Older Drivers & Expert Panel/field study & $\begin{array}{l}\text { Do edge lines improve } \\
\text { performance of older drivers? }\end{array}$ \\
\hline $\begin{array}{l}\text { Routes to Success: Maps for } \\
\text { Older Drivers }\end{array}$ & Feasibility study & $\begin{array}{l}\text { Develop maps/guides of routes } \\
\text { that are friendlier to ODs (e.g., } \\
\text { well-lit, good pavement } \\
\text { markings, lower speed limits, } \\
\text { etc.) }\end{array}$ \\
\hline $\begin{array}{l}\text { Routes to Success: Maps for } \\
\text { Older Pedestrians }\end{array}$ & Feasibility study & $\begin{array}{l}\text { Develop maps/guides of routes } \\
\text { that are friendlier to older peds } \\
\text { (e.g., well-lit, have crosswalks } \\
\text { and ped signal, etc.) }\end{array}$ \\
\hline $\begin{array}{l}\text { RTOR Restrictions and Traffic } \\
\text { Flow }\end{array}$ & Traffic flow study & $\begin{array}{l}\text { Do RTOR restrictions affect } \\
\text { traffic flow? }\end{array}$ \\
\hline $\begin{array}{l}\text { RTOR Restrictions and } \\
\text { Comprehension }\end{array}$ & Focus groups, paper \& pencil & $\begin{array}{l}\text { Do drivers and ped understand } \\
\text { RTOR restrictions (e.g., "no right } \\
\text { on red when peds are present")? }\end{array}$ \\
\hline $\begin{array}{l}\text { Safe Mobility: Priorities of } \\
\text { Roadway Improvements for } \\
\text { Older Adults }\end{array}$ & Expert Panel & $\begin{array}{l}\text { Develop and prioritize } \\
\text { implementation of improved } \\
\text { infrastructure for ODs and Ops. }\end{array}$ \\
\hline $\begin{array}{l}\text { Older Women's Transportation } \\
\text { Needs: Rural and Urban }\end{array}$ & $\begin{array}{l}\text { Survey of geographically diverse } \\
\text { cities \& towns }\end{array}$ & $\begin{array}{l}\text { Older women's transportation: } \\
\text { needs and current use }\end{array}$ \\
\hline At-Risk Women's Safety Issues & Focus Groups, Survey & $\begin{array}{l}\text { Older women's safety Issues } \\
\text { with public transportation }\end{array}$ \\
\hline $\begin{array}{l}\text { Car-Pooling Options for Older } \\
\text { Working Women }\end{array}$ & Workshop, Focus Group, PSA's & $\begin{array}{l}\text { Feasibility of older women's } \\
\text { carpooling }\end{array}$ \\
\hline
\end{tabular}




\section{Appendix 7}

Additional Research Projects Proposed by Expert Panel Members

\begin{tabular}{|l|l|l|}
\hline \multicolumn{1}{|c|}{ Title } & \multicolumn{1}{|c|}{$\begin{array}{c}\text { General Approach/ } \\
\text { Type of Study }\end{array}$} & $\begin{array}{c}\text { Desired Outcomes } \\
\text { (Question to be Answered) }\end{array}$ \\
\hline $\begin{array}{l}\text { Older Females' Crash Risk: } \\
\text { Disentangling Relationships } \\
\text { Examine higher crash rate for } \\
\text { Insight for Self-Regulation } \\
\text { interaction) }\end{array}$ \\
\hline Unlicensed Drivers & Evaluate subjects - survey & $\begin{array}{l}\text { Are patients aware of effects of } \\
\text { dementia, sleep apnea, } \\
\text { hypoglycemia, medications? }\end{array}$ \\
\hline Rate of At-Risk Status & $\begin{array}{l}\text { Keep unlicensed drivers off the } \\
\text { road }\end{array}$ \\
\hline Age-Based Screening & $\begin{array}{l}\text { Identify \% of older drivers that } \\
\text { are at-risk (or are unsafe to } \\
\text { drive) }\end{array}$ \\
\hline Age and Risky Conditions & $\begin{array}{l}\text { Define age cutoff for screening - } \\
\text { is there a change in curve? }\end{array}$ \\
\hline Keeping Good Programs Alive & $\begin{array}{l}\text { Define what age is associated } \\
\text { with conditions which impair } \\
\text { driving }\end{array}$ \\
\hline Medical Advisory Boards & $\begin{array}{l}\text { Sustainability of existing } \\
\text { programs }\end{array}$ \\
\hline
\end{tabular}


DOT HS 809322

August 2001

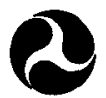

U.S. Department of Transportation

National Highwey 